\title{
Plant: soil interactions in temperate multi-cropping production systems
}

\author{
Jürgen Ehrmann • Karl Ritz
}

Received: 23 February 2013 / Accepted: 25 September 2013 /Published online: 6 November 2013

(C) Springer Science+Business Media Dordrecht 2013

\begin{abstract}
Background and scope Multi-cropping approaches in production systems, where more than one crop cultivar or species are grown simultaneously, are gaining increased attention and application. Benefits can include increased production, effective pest, disease and weed control, and improved soil health. The effects of such practices on the range of interactions within the plant-soil system are manifest via plant interspecific competition, pest and disease attenuation, soil community composition and structure, nutrient cycling, and soil structural dynamics. Interplant diversity and competition effectively increases the nature and extent of root networks, tending to lead to more efficient resource use in time and space. Increased competitive ability at a system level, and allelopathic interactions, can reduce weed, pest and disease severity. Soil biotic communities are affected by plant diversity, which can increase abundance, diversity and activity of functional groups. Attendant rhizospherelocated processes can facilitate nutrient uptake between component crops. Whilst there are few studies into multicropping effects on soil structure, it is hypothesised that such processes are manifest particularly via the role
\end{abstract}

Responsible Editor: Philippe Hinsinger.

J. Ehrmann $\cdot$ K. Ritz $(\bowtie)$

Environmental Science and Technology Department,

School of Applied Sciences, Cranfield University,

Cranfield, MK43 0AL, UK

e-mail: k.ritz@cranfield.ac.uk

J. Ehrmann

e-mail: juergen_ehrmann@t-online.de which the belowground biota play in soil structural dynamics. A deeper understanding of eco-physiological processes affecting weed, pest and disease dynamics in the context of multiple cropping scenarios, and breeding cultivars to optimise mutualistic and allelopathic traits of crop mixtures could significantly increase productivity and adoption of more sustainable farming practices.

Conclusions Wider consideration needs to be given to plant: soil interactions when crop plants are grown in the context of mixtures, i.e. as communities as opposed to monotonous populations. In particular, a better understanding is required of how root systems develop in the context of mixtures and the extent to which resultant interactions with the soil biota are contextdependent. A significant challenge is that crop cultivars or production systems optimised for monocultural circumstances should not be assumed to be most suited for multi-cropping scenarios, and hence alternative strategies for developing new production systems need to take this into account.

Keywords Intercropping · Plant interspecific competition $\cdot$ Soil biotic communities $\cdot$ Biological weed, pest and disease control $\cdot$ Nutrient facilitation . Soil structure

\section{Introduction}

Traditional farming practices, particularly in temperate regions, have largely been replaced with intensified and highly-mechanised systems founded upon monocultures 
both at the field and regional-scale (Whitmore and Schröder 2007; Malézieux et al. 2009; Lithourgidis et al. 2011). Modern agricultural systems greatly depend on managing soils using external inputs and soil disturbance regimes. By simplifying structurally diverse natural systems and by replacing the services these ecosystems provide (e.g. nutrient cycling, water regulation, micro-climate regulation, detoxification) with chemical and fossil-fuel based inputs and farming operations, and by depleting natural soil resources, intensive agricultural systems are arguably less resilient, compromising sustainability, as well as posing threats to the natural environment (Altieri 1999; de Vallavieille-Pope 2004; Malézieux et al. 2009).

Multi-cropping, also referred to as intercropping or mixed cropping, is the agricultural practice of growing multiple cultivars or crop species simultaneously in the same field for a significant part of their life cycle (Vandermeer 1989; Lithourgidis et al. 2011). Mixed cropping can be applied to field-crop species, pasture species, trees, or a combination thereof. Tree based intercropping systems (TBIs) are referred to as alleycropping or agroforestry. Vegetables have long been intercropped in horticultural systems, but have also been trialled in agricultural settings (Motisi et al. 2009; Kluth et al. 2010; Zhou et al. 2011).

Growing multiple crops simultaneously is a centuriesold practice and is still widely applied around the world, in contemporary terms mainly in tropical, small-scale subsistence farming (Lithourgidis et al. 2011). In temperate zones multi-cropping is receiving greater attention, particularly in forage production, in grass-clover/legume pasture mixtures (Anil et al. 1998; Whitmore and Schröder 2007; Lithourgidis et al. 2011) and in organic farming, where multi-cropping is considered to provide a biological means of maintaining soil health (Altieri 1995a; Malézieux et al. 2009), and reducing the frequency and severity of pest infestations (Trenbath 1993; de Vallavieille-Pope 2004; Saucke and Ackermann 2006).

Practical issues, such as drilling, sowing, spraying and harvesting, pose problems when adapting multiplecropping in highly mechanised agricultural systems. Differing growth cycles and requirements for nutrients and pesticides make it difficult for growers to adapt new systems in order to manage and harvest mixed crops (Anil et al. 1998; Tosti and Guiducci 2010; Lithourgidis et al. 2011). Such issues can be more easily overcome when crops are grown for forage or grazing where the marketability of the end product is of no concern (Anil et al. 1998). Crop models will also need to be adapted.
Multiple-crop models are challenged by the complex plant-soil interactions, which are key in understanding nutrient dynamics, interplant competition and disease resistance (Malézieux et al. 2009). Such models also need to accommodate soil processes and include concepts of community ecology (population dynamics, epidemiology, and the role of soil micro- and macro-organisms).

Numerous studies have reported how yield advantages in mixed cropping systems compared to sole crops are provided for by ecological processes. These include: (i) more efficient and complementary use of available resources and niches (Malézieux et al. 2009; Tosti and Guiducci 2010); (ii) facilitation via the roots (Vandermeer 1989; Hauggaard-Nielsen and Jensen 2005); (iii) enhanced soil fertility by intercropping nitrogen-fixers (HauggaardNielsen and Jensen 2005); (iv) increased resilience against pests and diseases (Trenbath 1993); (v) increased abiotic stress resistance due to higher levels of functional diversity within the system and resultant complex interactions between associated ecological and biochemical processes (Eisenhauer 2012; George et al. 2012).

More recently, attention has shifted towards the potential of mixed cropping in soil conservation and the ecosystem services that soils provide (Altieri 1999; Whitmore and Schröder 2007; Malézieux et al. 2009). By intercropping trees and by increasing soil cover and root presence in the topsoil; run-off rates, the risk of soil erosion, salinity and nitrate leaching are reduced (Wang et al. 2011; George et al. 2012), while key nutrients are being restored (Altieri 1999; Whitmore and Schröder 2007). Further, agroforestry systems sequester more carbon through crop stands and affect organic matter inputs (Malézieux et al. 2009; Oelbermann and Echarte 2011; George et al. 2012).

Although the majority of research on multiple-crop systems has focused on aboveground effects on the component crops, belowground interactions have far more significant impacts on combined plant development (Martin and Snaydon 1982; Hauggaard-Nielsen and Jensen 2005; Thorsted et al. 2006). Only recently attention has shifted towards the complexity of belowground interactions between crops and the soil system (Tosti and Thorup-Kristensen 2010). A framework for linkages between the individual interacting belowground components is given in Fig. 1.

The aim here is to review the effects of temperate arable multiple-crop systems on belowground processes within the plant-soil system, considering competition, soil microbial composition and structure, weed, pest 


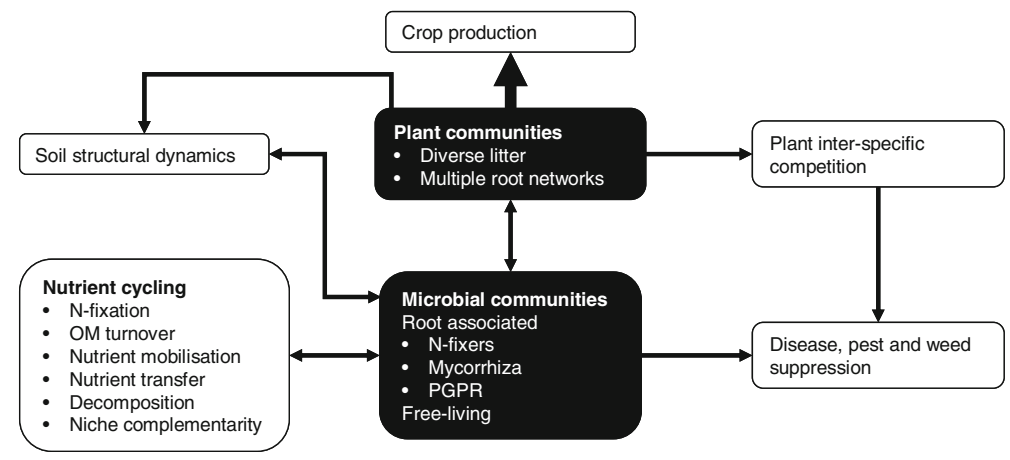

Fig. 1 Interactions within the plant-soil system in multiple crop systems. Components denotes in black boxes, processes in white boxes. The diagram shows how through multiple-crop arrange-

and disease control, nutrient cycling, organic matter and soil structural dynamics. Gaps in knowledge are identified and recommendations for further research are made, which could potentially offer significant insight into how such plant-soil systems can be managed more productively and sustainably. We confine the scope of this review to arable farming systems in temperate regions, which include common cereal-legume intercrops, cereal variety mixtures and agroforestry, but examples from pastures will also be drawn upon, where similarities exist. ments root systems can alter their environment directly and indirectly via rhizosphere processes (discussed in this review) to express mutually beneficial traits

We further confine this review to the belowground components influencing agricultural production systems, and the interactions and physical, chemical and ecological soil processes linking them.

\section{Range and types of multiple-crop systems}

Malézieux et al. (2009) proposed the following criteria to classify mixed cropping arrangements: (i) the

Table 1 Different forms of species' mixtures in agricultural systems. Systems are classified according to a gradient of complexity, including the number and type of plant species (annual vs. perennial), the horizontal and vertical structure of the mixture

\begin{tabular}{|c|c|c|c|}
\hline Type of system & $\begin{array}{l}\text { No. of } \\
\text { species }\end{array}$ & $\begin{array}{l}\text { Number } \\
\text { of strata }\end{array}$ & Examples/location \\
\hline \multicolumn{4}{|l|}{ Annual crops } \\
\hline Combination (intraspecific mixture) & 1 & 1 & Cereals variety mixtures and populations (Europe) \\
\hline $\begin{array}{l}\text { Relay cropping (time overlay only during one part of } \\
\text { life cycle of each species) }\end{array}$ & 2 & 1 or 2 & $\begin{array}{l}\text { Maize/beans (Africa), undersowing maize/clover } \\
\text { (Europe) }\end{array}$ \\
\hline Row intercropping (growing two or more species in rows) & $\geq 2$ & 1 or 2 & Cereals/herbaceous legumes and grasses (Europe) \\
\hline Mixed intercropping (no distinct row management) & $\geq 2$ & 1 & Annual grassland (Europe) \\
\hline \multicolumn{4}{|l|}{ Perennial crops } \\
\hline Perennial grasses & $\geq 2$ & 1 & Grassland (North America, Europe, Australia) \\
\hline \multicolumn{4}{|l|}{ Agro-forestry } \\
\hline Sequential Agro-forestry (crop temporarily mixed with trees) & 2 & 2 & Pineapple/rubber tree (humid Asia) \\
\hline \multicolumn{4}{|l|}{ Row Agro-forestry } \\
\hline Crop under service trees & 2 & 2 & Maize/green manure/legume tree (Tropics) \\
\hline Herbaceous crop under tree crop & 2 & 2 & Cereal/wood tree (Europe, N. America) \\
\hline Service plants under tree crops & $\geq 2$ & 2 & Grass/vineyard, clover/orchard (Europe) \\
\hline Tree crops & $\geq 2$ & $1-3$ & Fruit/nut/timber (Europe) \\
\hline Complex agro-forestry (trees, shrubs and crops) & $\geq 2$ & $2-5$ & Home gardens (Tropics), Permaculture \\
\hline
\end{tabular}

Adapted from Malézieux et al. (2009), principally to highlight examples from temperate contexts 
permanence of a specific crop assemblage, or conversely the frequency of rotation; (ii) the number, type and level of spatio-temporal occurrence of crops within a field; (iii) the percentage of tree canopy cover in a field (agroforestry systems). The different multiplecrop arrangements, ranging from mixed pastures and leys to complex agroforestry systems have been described by Malézieux et al. (2009) and Lithourgidis et al. (2011), and are summarised in Table 1. Crop rotations, where different crops are grown successively, in order to prevent the accumulation of soil-borne pathogens and the depletion of soil resources, are essentially a form of multi-cropping in time as well as space, and are not included in the scope of this review.

\section{Plant interspecific competition}

The growth dynamics of root systems significantly affect whole-plant growth, especially when roots interact in a multiple-crop circumstance, and are important in understanding nutrient uptake (Hauggaard-Nielsen et al. 2001a). However, few studies have been carried out to systematically compare the root distribution of crops when grown in combination, rather than as sole crops. This is largely due to the technical challenges involved in studies under field conditions, and the time and costs involved (Hauggaard-Nielsen et al. 2001a; Li et al. 2006). Where yield advantages are manifest, this is generally considered to be due to more efficient and complementary resource use, and largely attributed to belowground interactions and root facilitation (HauggaardNielsen and Jensen 2005).

Facilitative plant processes are interactions between plants (and microorganisms) which tend to be beneficial for each other's growth, as opposed to competitive interferences, which tend to limit the growth of non-dominant species or both (Vandermeer 1989). Facilitative root interactions can occur directly via competitive adaptations of the root architecture, and/or indirectly via: nitrogen transfer between legumes and non-legumes; exploitation of soil via mycorrhizal networks; soil-plant processes which can mobilise resources, such as the exudation of amino acids and extra-cellular enzymes, acidification, and biofumigation (Hauggaard-Nielsen and Jensen 2005). In nutrient poor conditions such facilitative processes have the greatest impact due to plant responses and resulting modification of interspecific competition (HauggaardNielsen and Jensen 2005; Inal and Gunes 2008).
Some facilitative root interactions and processes involved directly affect the growth and distribution of the root network in the soil, potentially leading to or enhancing niche complementarities. Others, driven by the root system, affect nutrient uptake and mobilisation, soil biochemistry, associated microorganisms and mutualistic relationships and allelopathic effects on soil-borne pathogens, and are considered below.

There are two manners by which interspecific facilitation between plants can occur. Firstly, via asymmetric facilitation, where one crop can alter the environment of the other positively, and enhance growth of the other species. This was observed in maize (Zea mays)-wheat (Triticum aestivum) intercrops, where maize facilitated growth and nutrient uptake in wheat, but not vice versa (Li et al. 2006). Similarly, compounds released by chickpea (Cicer arietinum) roots enhanced root and shoot growth in wheat, but there was no apparent effect upon the chickpea (Wang et al. 2007a). The second manner is via symmetric interspecific facilitation, where both species are affected positively by each other's presence. When Li et al. (2006) intercropped maize with faba beans (Vicia faba), both crops positively affected each other's growth and nutrient economy. Peanuts (Arachis hypogaea) were found to increase $\mathrm{P}$ uptake in maize and barley (Hordeum vulgare) when intercropped, while maize and barley enhanced micro nutrient $(\mathrm{K}, \mathrm{Fe}, \mathrm{Zn}$, $\mathrm{Mn}$ ) content in peanuts (Zhang and Li 2003; Inal and Gunes 2008). Although root facilitation can enhance plant growth in intercrops, inhibiting effects have also been observed in the field (Wang et al. 2007a). Facilitative root interactions are driven by a range of ecological processes, which are influenced by local climatic and growth conditions, soil type and crop selection (Hauggaard-Nielsen and Jensen 2005; Wang et al. 2007a; Li et al. 2010), which explain the variability of these interactions, their direction and effects on crop growth.

The majority of resources necessary for plant growth (i.e. nutrients, minerals, water) lie belowground, whereas aboveground, plants principally compete for incident radiation. Hence, as a consequence of the soil matrix defining the plant's habitable volume, the main ecological processes affecting the coexistence of multiple crops are belowground competition for space and resources, rather than shoot competition for light (Martin and Snaydon 1982). However, Mushagalusa et al. (2008) have found that in potato (Solanum tuberosum)-maize intercrops interspecific competition was found to be driven mainly by light availability. Similarly, in 
agroforestry systems the competition for radiation rather than belowground resources could be the limiting factor for crops grown in rows near trees. Water uptake was not found to be restricted in a hedge-intercrop and two maize intercrop systems (McIntyre et al. 1997; Lei et al. 2005). In fact, water use efficiency and yields were increased.

The spatial distribution and density of root networks in the soil determine the ability of a crop to acquire nutrients and water. Competition between different crop mixtures can take on different forms and species can display differences in aggressiveness towards each other. Multiple crops are able to exploit a larger soil volume if the root architecture of the constituent types is complementary (Martin and Snaydon 1982; McIntyre et al. 1997; Hauggaard-Nielsen and Jensen 2005).

\section{Temporal distribution of roots}

Here, root competition is discussed in terms of temporal dimensions, i.e. how rapidly root development occurs, and spatial aspects, in terms of length, depth, density, and total soil volumes occupied. During the early growth stages the competitive ability of a crop is an important factor in its successful establishment and dominance (Tosti and Thorup-Kristensen 2010), hence rapid root development can give plants competitive advantages over their neighbours. For example, in barley-pea (Pisum sativum) intercrops, a tendency for barley roots to penetrate the soil profile and start taking up nitrogen and water before pea roots appear was found. The stress imposed on peas then increased root exudation in peas, which altered the spatial and temporal distribution and uptake of resources in the system (Hauggaard-Nielsen and Jensen 2005). Competition between pea and intercropped cereals in the early stages increases $\mathrm{N}_{2}$ fixation by the legume. This advantage however, faded when peas were sown before barley (Martin and Snaydon 1982). Legumes generally display different strategies to cereals and red beet (Beta vulgaris) in colonising the soil, but may not be able to counteract the early competitive advantage, of red beet, wheat and barley (Martin and Snaydon 1982; Hauggaard-Nielsen et al. 2001a; Tosti and Thorup-Kristensen 2010).

These results suggest that detrimental effects on crop growth can, at least in part, be minimised by appropriate management practices, through selection of appropriate cultivars, asynchronous timing of sowing (relaycropping, sequential intercropping) and relative planting densities, allowing the weaker component crop to establish prior to or alongside the dominant crop (Hauggaard-Nielsen et al. 2001a).

Spatial root distribution and root architecture

The way in which crops colonise the soil profile affects the spatial niches and thence the total soil volume occupied by the crop, and in turn affects its capability to exploit belowground resources. Interactions between roots also play an important role in the way resources are used more efficiently in multiple-crop systems. For example, the roots in sorghum (Sorghum bicolor)-pigeon pea (Cajanus cajan) and maizecowpea (Vigna unguiculata) mixtures typically intermingle freely, whereas wheat and barley tended to dominate over legumes and restrict leguminous root development into deeper soil layers (HauggaardNielsen et al. 2001a; Hauggaard-Nielsen and Jensen 2005; Li et al. 2006; Tosti and Thorup-Kristensen 2010). When wheat was grown in combination with maize, wheat occupied a larger soil volume and extended its roots beneath maize ( $\mathrm{Li}$ et al. 2006). However, maize was able to recover from early disadvantages after wheat was harvested by occupying more belowground space at later stages (Li et al. 2011).

Different rooting patterns and architecture usually present in crop mixtures affect the competitive abilities and resource utilisation by crops. In a red beet-clover (Trifolium spp.) system, differences in root architecture, and spatial and temporal differences in root development, restricted resource exploitation by the legume to the upper soil layers Red beet was shown to gain a competitive advantage by rapidly developing a high root intensity, thus maximising the soil volume it occupied, while minimising the soil volume in common with the legume (Tosti and Thorup-Kristensen 2010).

Contrasting patterns of fine and coarse root biomass of different plants, and distribution throughout the soil profile can also lead to complementarities in resource use (Craine et al. 2003; Zarea et al. 2009). Beans (Phaseolus vulgaris) were shown to produce higher root biomass compared to barley. The observed competitive advantage of barley was suggested to have resulted from its much finer roots (Martin and Snaydon 1982). Strong relationships were found between the amount of fine root biomass per unit of soil and the depletion of soil resources (Craine et al. 2003). In wheat-brassica mixtures, the longer roots of the brassica allowed the plants to utilise more phosphorus 
(Wang et al. 2007a). Due to its deep taproot system allowing for higher water uptake, lucerne (Medicago sativa) was able to outcompete chicory (Cichorium intybus) and red clover in mixed herb leys under dry soil conditions in New Zealand (Goh and Bruce 2005).

Tree species are able to intercept nutrients that are being transported below the root zone of most herbaceous/graminaceous crops, and draw further upon nutrients from the subsoil. However, studies show variable results and are apparently inconclusive (Lehmann 2003). The subsoil-resource use of trees, but also the ability to bring nutrients from deeper zones into the surface layers, via deposition in leaf litter, which then can be exploited by other components within the system, was suggested to be one of the main reasons for incorporating trees into agricultural systems, so-called agroforestry systems (Sanchez 1995; Farrell and Altieri 1995).

Inter- vs. intra-specific root competition

Several studies have investigated how the effects of interspecific root competition differ from intraspecific root competition by comparing rooting patterns of crops grown in mixtures and as sole crops. For example, in cereal-cereal, cereal-legume and cereal-groundnut and peanut intercrops, plants have been found to increase root growth, root length densities, rooting depth and the total soil volumes occupied when compared to sole crops (Kamh et al. 1999; El Dessougi et al. 2003; Hauggaard-Nielsen and Jensen 2005; Li et al. 2006; Inal and Gunes 2008; Tosti and Thorup-Kristensen 2010; Li et al. 2011). Further, in red beet intraspecific competition reduced total root development and biomass of red beet by $50 \%$ when sown as a sole crop at same densities as when intercropped (Tosti and ThorupKristensen 2010). Due to interspecific competition, plants alter their root morphology (Li et al. 2011) and develop a deeper root system early on, enabling them to exploit nutrients from deeper soil layers, thus making the system less prone to water stress, and enabling a more complementary use of water and nutrients between the component crops. According to HauggaardNielsen and Jensen (2005), early interspecific belowground competition can shift towards facilitation later on in the growing season, which further enhances root growth and activity, which may explain why multicropping systems generally promote root growth (Yong et al. 2012). Technical developments are required to facilitate further research into root development and competition, and rhizosphere processes in multiple-crop systems. Advances in X-ray and fluorescence imaging technologies (e.g. Roumet et al. 2006; Ritz 2011; Faget et al. 2013) offer notable potential in this respect.

Exploitation of complementarity in root system morphology and function between species appears to offer great potential; in a sense, this occurs in natural plant stands and successional seres via processes of adaptation and evolution. However, little consideration appears to have been given to the concept that the same crop species with contrasting root phenotypes could be a potential strategy to increase belowground resource utilisation whilst maintaining aboveground monotony in harvestable product. There is clearly sufficient potential variation in root phenotypes (e.g. Lynch and Brown 2012) to underpin this concept, notwithstanding the high degree of plasticity in the development of root architectures (Osmont et al. 2007). This may be challenging however since it requires crop breeding programmes to explicitly characterise root systems in a manner suited to highthroughput screening, and eventually in a real soil context, which is not straightforward. Non-invasive means of visualising root morphology such as X-ray CT scanning (Mooney et al. 2012) will likely enable such approaches.

\section{Nutrient uptake and cycling}

Nutrient dynamics and uptake are by far the most intensively studied area of multiple-crop systems. Interactions between physical, biological and chemical rhizosphere processes affect the way in which nutrients are cycled differently in intercrops, compared to sole crops. Differences to monocultures derive from: (i) interplant competitive interactions, which can lead to complementary resource use in time, space and form (Liebman 1995; El Dessougi et al. 2003; Li et al. 2008); (ii) nutrient facilitation, i.e. the mobilisation and transfer of nutrients to component crops within the system (Liebman 1995; Wang et al. 2007b; Betencourt et al. 2012); (iii) differences in OM inputs (Bambrick et al. 2010; Oelbermann and Echarte 2011). Rhizosphere processes link plant and soil processes and are important drivers of the plant-soil system. Rhizodeposition transfers energy and recycles organic matter and nutrients between crops, microorganisms and the soil and thus is important for crop productivity (Zhang et al. 2002), and rhizosphere processes are significantly modified by intercropping (Zhang et al. 2004). 


\section{Soil organic carbon}

Organic matter inputs are closely related to soil fertility and soil organic carbon (SOC) contents. SOC provides the energy to enable all rhizosphere processes. In plantsoil systems enzymes, derived from microorganisms, plant roots and plant and animal residues play a significant role in organic matter decomposition and nutrient cycling (Zarea et al. 2011). Multi-cropping, with different plant species and specific functional groups, such as $\mathrm{N}$-fixing legumes, affect the abundance, activity and composition of soil enzymes and decomposer communities (Zarea et al. 2009). Hence differences in the amount and type of SOC present in a multiple-crop context would be hypothesised. Studies on soybeanmaize intercrops found that intercropping had little influence on SOC turnover rates (Oelbermann and Echarte 2011). However, after conversion of grassland to agriculture, a shift in carbon derived from either $\mathrm{C}_{3}$ or $\mathrm{C}_{4}$ species occurred in monocultures, whereas in intercrop systems a mixture of carbon sources remained (Oelbermann and Echarte 2011).

In agro-forestry systems, SOC content was higher within close proximity of trees, which was related to litter fall (Thevathasan et al. 2004; Bambrick et al. 2010). Hence, the choice of tree species can affect the heterogeneity of SOC distributed in the system (Bambrick et al. 2010). Soil organic carbon content was also positively correlated to plant-available $\mathrm{N}$ content (Bambrick et al. 2010), indicating that the incorporation of trees into agroecosystems can be beneficial to soil fertility and crop productivity, although yield data was not recorded in this study. Increases in SOC in agroforestry systems ranged from 12 to $77 \%$ (Bambrick et al. 2010). According to George et al. (2012) plant diversity, productivity and carbon sequestration are interconnected. Carbon sequestration was found to be significantly higher in more diverse agroforestry systems compared to conventional crop systems (Thevathasan et al. 2004).

\section{Nitrogen}

\section{Nitrification}

Autotrophic ammonia-oxidising bacteria (AOB) are involved in the oxidation of ammonia to nitrite and thus, play a key role in $\mathrm{N}$ availability to plants, particularly in the rhizosphere (Song et al. 2007b). Little is known about how plant species differ in community composition of ammonia oxidising microorganisms, and to what extent community composition may affect nitrification (Song et al. 2007b). In studies on wheatfaba bean and maize-faba bean intercrops, Song et al. (2007b) found that $\mathrm{NO}_{3}$ and $\mathrm{NH}_{4}$ concentrations changed in the rhizosphere of wheat and maize when intercropped with faba bean. However, changes in AOB community composition were not directly related to changes in $\mathrm{NO}_{3}$ concentrations.

\section{Symbiotic nitrogen fixation}

In low-input cereal-legume intercrops, the most important source of nitrogen is derived from the atmosphere and fixed by legume species (Stern 1993). Biological N fixation contributes a large proportion to the terrestrial $\mathrm{N}$ budget (Bever et al. 2010). In some cases $\mathrm{N}$-fixing bacteria can supply up to $100 \%$ of the total $\mathrm{N}$ required for plant growth and grain development (Alves et al. 2003). However, as well as legume-based symbiotic $\mathrm{N}$ fixation, associative forms of $\mathrm{N}$ fixation, such as those in the rhizospheres of graminaceous plants such as sugar cane (Saccharum officinarum), maize and sorghum (Monteiro et al. 2012) also occur and can be significant in terms of amounts of $\mathrm{N}$ fixed and apparently transferred to the associated plants (Dobbelaere et al. 2003). Dinitrogen fixed by legumes, is either taken up by the legume itself, or released during growth, at maturity or when plant tissues decay (Stern 1993). In multiple-crop systems, N released may become directly available to the component crop, or is incorporated into the organic matter of the soil, where it is transformed, of which some forms may then become available to the component crop, succeeding crops, or is leached out of the root zone or lost to the atmosphere (Stern 1993; Pappa et al. 2011).

Hauggaard-Nielsen et al. (2001b) found a 40-80\% increase in $\mathrm{N}_{2}$ fixation in a pea-barley intercrop compared to pea sole crops, and up to $95 \%$ of the total pea $\mathrm{N}$ accumulated in intercrops was derived from the atmosphere. Daily $\mathrm{N}$ fixation was lower in ryegrass (Lolium perenne)-white clover (Trifolium repens) pastures, compared to more diverse pasture systems (Goh and Bruce 2005). However, due to lower legume density in intercrops, the total amounts of $\mathrm{N}$ derived from the atmosphere are typically lower, although the percentage of fixed $\mathrm{N}$ per plant increases (Neumann et al. 2007). 
Factors affecting nitrogen dynamics

Rates of $\mathrm{N}$ fixation are influenced by abiotic factors including soil acidity, salinity, temperature, moisture (Stern 1993; Goh and Bruce 2005), and compaction (Riesinger and Herzon 2010); and by biotic factors such as legume growth, biomass and health (Stern 1993; Riesinger and Herzon 2010; Isaac et al. 2012), which, in a multiple-crop circumstance is affected by interplant competition (Giller and Cadisch 1995; Neumann et al. 2007) and other biological and chemical interactions between crops, microorganisms and the soil system (Stern 1993; Bever et al. 2010), and the presence of AMF (Zarea et al. 2011).

Fertiliser application affects $\mathrm{N}$ fixation in intercrops in two ways. It can (i) enhance legume growth, leading to increased nodulation and nitrogen fixation (Abdel Wahab and Abd-Alla 1996), but also (ii) decrease the amounts of $\mathrm{N}_{2}$ derived from the atmosphere by supplying sufficient fertiliser $\mathrm{N}$ to the soil, thus eliminating the necessity for legumes to form symbiotic relationships with Rhizobia species (Boller and Nösberger 1988). Interplant competition in cereal-legume intercrops can significantly affect the rates at which $\mathrm{N}$ is fixed and accumulated, by increasing the demand for atmospherically derived $\mathrm{N}_{2}$, as most cereals are stronger competitors and deplete soil $\mathrm{NO}_{3}$ sources in the rhizosphere of the component legume (Zhang et al. 2004; Szumigalski and Van Acker 2006; Riesinger and Herzon 2010). Competitive stresses forcing legumes to increase $\mathrm{N}_{2}$-fixation also lead to complementary N use (Jensen 1996; Hauggaard-Nielsen and Jensen 2001). This has been shown for oat-pea (Neumann et al. 2007), barley-faba bean (Danso et al. 1987), barley-pea (Hauggaard-Nielsen et al. 2001b) and wheat-faba bean (Wang et al. 2007b) intercrops.

\section{Nitrogen transfer}

There are two ways in which $\mathrm{N}$ is transferred from an $\mathrm{N}$ fixing crop to a non-N-fixing component crop, namely via indirect and direct routes. Indirect transfer occurs when N, in form of ammonium, amino-acids or sloughed-off cells and leaf litter, is deposited in the rhizosphere by the legume and subsequently transformed by microorganisms, making it available to the component crop (Kurdali et al. 1990; Stern 1993; Hauggaard-Nielsen and Jensen 2005; Song et al. 2007b; Dahlin and Stenberg 2010). In pot experiments studies have shown that up to $19 \%$ of total $\mathrm{N}$ uptake in barley plants was derived from pea plants (Jensen 1996) and $5 \%$ of wheat $\mathrm{N}$ was derived from faba bean (Xiao et al. 2004) via rhizodeposits. However, such results could not be replicated in the field (Hauggaard-Nielsen and Jensen 2005). Indirect N transfer via leaf litter significantly contributed to the total $\mathrm{N}$ uptake of the component crop, in clover leys, TBIs and forestry (Kurdali et al. 1990; Dahlin and Stenberg 2010). Direct $\mathrm{N}$-transfer from legumes to the component crop occurs between living plants, via mycorrhizal connections (Stern 1993; He et al. 2003; Yao et al. 2003; Szumigalski and Van Acker 2006). The bulk of $\mathrm{N}$ acquired by legumes and transferred to the component crop only becomes available after senescence (Hauggaard-Nielsen et al. 2003). Several studies have assessed the increase in $\mathrm{N}$ uptake due to intercropping, and have found that in general: (i) cereallegume/ $\mathrm{N}$-fixing tree intercrops and $\mathrm{N}$ transfer increased $\mathrm{N}$ uptake in both crops grown in close proximity (Seiter and Horwath 1999; Zhang et al. 2004); (ii) N-transfer is greater in perennial systems, such as clover-grass pastures, compared to annual crops (Jørgensen et al. 1999; Høgh-Jensen and Schjoerring 2001); (iii) no beneficial effects on $\mathrm{N}$ uptake have been recorded in cereal-cereal intercrops (Wang et al. 2007a). The rate at which $\mathrm{N}$ is transferred between crops is affected by biomass ratio between the component crops (Dahlin and Stenberg 2010) and the presence of mycorrhizal connections (Zarea et al. 2009). In nutrient poor conditions, $\mathrm{N}$ transfer increased when roots were able to interact (Xiao et al. 2004; Thorsted et al. 2006). Root systems are said to interact if their respective root systems grow in proximity of $0.5 \mathrm{~mm}$ of root exudates (Zhang et al. 2004). Dahlin and Stenberg (2010) estimated total N transfer within mixed leys from clover to ryegrass to make up 30-57 \% of grass $\mathrm{N}$ and $13-26 \%$ in clover $\mathrm{N}$.

When assessing $\mathrm{N}$ dynamics studies differentiate between $\mathrm{N}$ uptake and resulting effects on grain $\mathrm{N}$ content and quality, and $\mathrm{N}$ released into the soil enhancing soil fertility and crop production, potentially also for subsequent crops. Increased $\mathrm{N}$ availability in the rhizosphere of cereal component crops have been reported in multiple-crop systems, while $\mathrm{N}$ pools depleted in the rhizosphere of the leguminous component (Song et al. 2007a). In wheat undersown with clover, inorganic soil $\mathrm{N}$ content was higher in intercrops compared to single wheat, where $\mathrm{N}$ was also found deeper in the soil profile (Bergkvist et al. 2011). In absence of fertilisation legume intercrops show great spatial and temporal variation in $\mathrm{N}$ availability (Hauggaard-Nielsen et al. 2010; Bergkvist et al. 2011). Although more $\mathrm{N}$ may become available in 
the rhizosphere of intercropped species, plant $\mathrm{N}$ uptake also increases, hence intercrops are likely to deplete rather than restore soil $\mathrm{N}$ in low or no-input farming systems (Hauggaard-Nielsen et al. 2001b).

\section{Phosphorus}

Phosphorus is a limited and highly immobile plant nutrient and often found in fixed organic compounds, or in form of $\mathrm{Ca}$ phosphates and $\mathrm{Fe}$ and $\mathrm{Al}$ phosphates, which are not directly extractable by plants (Bertrand et al. 2003). Several plants have developed mechanisms by which soil $\mathrm{P}$ can be mobilised into forms which can then be utilised by them and by plants growing in close proximity, such as that roots can interact (Zhang et al. 2004). Mechanisms by which $\mathrm{P}$ cycling and plant uptake is affected by multiplecrop arrangements include complementary $\mathrm{P}$ use and $\mathrm{P}$ facilitation (Li et al. 2007; Hinsinger et al. 2011).

\section{Complementary phosphorus use}

Different soil types harbour different forms of $\mathrm{P}$, and plants tend to employ different $\mathrm{P}$ acquisition strategies according to the type of soluble $\mathrm{P}$ prevalent in the soils in which they grow. As different plant species have developed different adaptations to mobilise and access different forms of soil P, complementary P use can be exploited within multiple-crop systems (Li et al. 2008). Component crops accessing different $\mathrm{P}$ pools due to organic acid exudation reduce interplant competition within the system. Such effects have been found in white lupine-wheat (Hocking 2001; $\mathrm{Cu}$ et al. 2005) and wheat and common bean (Li et al. 2008) intercrops. A combination of niche complementarity and facilitation was found to be the cause for an increase in wheat growth in a wheat-common bean intercrop ( $\mathrm{Li}$ et al. 2008).

More P may be acquired in intercrops compared to sole crops, simply by increasing root length and densities, or due to differences in growth and rooting patterns, and accessing spatially and temporally different soil $\mathrm{P}$ pools ( $\mathrm{Li}$ et al. 2007). This has been shown for canolawheat and maize-groundnut intercrops (El Dessougi et al. 2003; Wang et al. 2007a). When intercropped, maize plants accessed more and different soil $\mathrm{P}$ sources compared to groundnut and maize sole crops, due to a combination of increased soil volume occupied, complementary $\mathrm{P}$ sources, and facilitation by groundnut (El Dessougi et al. 2003).
Phosphorus facilitation

P facilitation describes mechanisms by which one plant may enhance $\mathrm{P}$ uptake by another plant. Mechanisms of $\mathrm{P}$ facilitation in intercrops include: rhizosphere acidification; exudation of carboxylates and other Pmobilising compounds; secretion of phosphatase; release and activation of enzymes; and association with microorganisms (Inal et al. 2007; Wang et al. 2007a; Li et al. 2008; Betencourt et al. 2012). According to the stress-gradient-hypothesis, facilitative mechanisms of $\mathrm{P}$ uptake act more effectively under low $\mathrm{P}$ conditions or competitive P stresses (Betencourt et al. 2012).

Root-induced $\mathrm{pH}$ changes are the most effective process of making P available to plants (Hinsinger 2001; Hinsinger et al. 2011). Plants can alter $\mathrm{pH}$ levels in the rhizosphere by excreting organic acids, such as carboxylates, malic and citric acids ( $\mathrm{Li}$ et al. 2007) and as a result from N-fixing processes (Hinsinger et al. 2003; Li et al. 2008). Thus, organic $P$ sources can be mobilised and made available for plant uptake, depending on the types of $\mathrm{P}$ present in different soil types (calcareous or acidic). In alkaline soils inorganic $\mathrm{P}$ is mainly present in the form of $\mathrm{Ca}$ phosphates, whereas in acidic soils, $\mathrm{P}$ adsorbed into $\mathrm{Fe}$ and $\mathrm{Al}$ oxides are dominant (Bertrand et al. 2003). The solubility of Ca phosphates increases with decreasing $\mathrm{pH}$, whereas the solubility of $\mathrm{Fe}$ and $\mathrm{Al}$ oxides increases with increasing $\mathrm{pH}$ ( $\mathrm{Li}$ et al. 2010). In calcareous soils, several studies have found that $\mathrm{P}$ facilitation between cereal-legume intercrops occurred due to rhizosphere $\mathrm{pH}$ decreases as a result from (i) the $\mathrm{N}_{2}$ fixing process (Hinsinger et al. 2003; Wang et al. 2007a; Li et al. 2008; Betencourt et al. 2012; Isaac et al. 2012), and (ii) organic acid exudation (Horst and Waschkies 1987; Ae et al. 1990; Cu et al. 2005; Li et al. 2007). Such studies suggest that several mechanisms may act simultaneously. In acidic soils legumes can increase rhizosphere $\mathrm{pH}$ through a combination of different processes occurring during legume root decomposition. Decaying legume residues contain excess cations, organic anions and carboxylates (Li et al. 2010; Tang and Yu 1999). Intercrop studies found that soil $\mathrm{pH}$ increased only when cereals were intercropped with legumes/brassicas, but not when monocropped (Wang et al. 2007a, b; Li et al. 2010). Although these processes do occur, Li et al. (2010) found no growth benefits in legume-maize intercrops in acidic soils.

Plants can further increase the acquisition of $\mathrm{P}$ via the release or activation of specific enzymes (Neumann 
and Römheld 1999; Inal et al. 2007). Phosphatase can catalyse the release of phosphate from organic soil $\mathrm{P}$ pools (Tarafdar and Jungk 1987). Many plant species can increase the release of phosphatase under low $\mathrm{P}$ conditions and under competitive $\mathrm{P}$ stress, as occurs in multi-cropping systems (Tarafdar and Jungk 1987). Facilitation of $\mathrm{P}$ uptake in wheat due to phosphatase release by chickpea was found to increase wheat growth. In dual cultivar wheat, and wheat-brassica intercrops, no facilitation of $\mathrm{P}$ uptake was found, as attributed to both plant types releasing insufficient amounts of phosphatase (Wang et al. 2007a).

\section{Other nutrients}

Similar to the roles of legumes in P mobilisation, the acidifying effect of atmospheric $\mathrm{N}_{2}$-fixation solubilises other nutrients, such as potassium, calcium and magnesium, which otherwise remain fixed in plant unavailable forms. This process can lead to facilitation when non-leguminous crops and legumes are intercropped (Hauggaard-Nielsen and Jensen 2005).

\section{Potassium}

Mineral nutrient facilitation was observed in barleylegume intercrops, where root competition increased the mineral content in barley, but did not limit $\mathrm{P}$ and $\mathrm{K}$ content in legumes significantly (Martin and Snaydon 1982). Other studies have shown that subsoil K uptake in spring cereals can account for up to $50 \%$ of total $\mathrm{K}$ uptake (Kuhlmann 1990) and up to $55 \%$ in ryegrass and clover mixtures (Witter and Johansson 2001). Hence, it is possible that, due to the deeper root systems generally found in multiple-crop systems, such subsoil $\mathrm{K}$ resources can be utilised more effectively, when crops are subjected to interspecific competition.

Iron

In calcareous soils, iron chlorosis is one of the most growth limiting factors for many crops (Zhang et al. 2004). Plants have developed different response mechanisms in coping with iron deficiency in calcareous soils. These are: increased reductase activity, enhanced proton release and exudation of reductants from roots (Marschner et al. 1989); and excretion of phytosiderophores into the rhizosphere (Römheld 1991), similar to P acquisition.
How these two different strategies are beneficial in intercrops has been shown by Zuo et al. (2003). Maize plants have a high resistance to iron deficiency, as they are capable of increasing their iron uptake efficiency by releasing phytosiderophores. Peanuts have different response mechanisms but are less efficient. When grown in combination with maize, and even more so with barley, oats and wheat, iron concentrations in peanut plants were shown to increase when their root systems were able to interact, compared to peanut monocultures (Zuo et al. 2003; Zuo and Zhang 2008).

\section{Other metals}

Li et al. (2004) have shown that mineral nutrient uptake depends on root interactions and type of $\mathrm{P}$ present in the soil. In wheat-chickpea intercrops, mutual facilitation of mineral nutrients in general was found to strongly depend on the form of extractable P present in the soil. Under field conditions, where P sources were not modified, Gunes et al. (2007) found that, intercropping wheat and chickpea increased shoot concentrations of $\mathrm{Zn}$ and $\mathrm{Mn}$ in both crops. Further it increased $\mathrm{P}, \mathrm{K}$, and $\mathrm{Fe}$ concentrations in wheat, while reducing $\mathrm{N}, \mathrm{P}$ and $\mathrm{K}$ concentrations in chickpea. The mineral content of seeds was also increased in both crops. Intercropping cereals with peanut in calcareous soils increased $\mathrm{Zn}$ and $\mathrm{Cu}$ concentrations in peanut plants (Zuo and Zhang 2008). Berseem clover (Trifolium alexandrinum) intercropped with either ryegrass or oat was able to increase its $\mathrm{Mn}$ influx by a factor of four (Arneja and Sadana 2012).

\section{Nutrient losses}

As multiple-crop systems can utilise nutrients more efficiently they may deplete rather than restore nutrients under low-input regimes (Hauggaard-Nielsen et al. 2001b). Crops grown in combination also develop more extensive and deeper root systems, thereby recovering more resources from deeper soil layers (El Dessougi et al. 2003; Yong et al. 2012). These two effects can reduce the risk of nutrient leaching and the consequent negative environmental impacts. This is of particular importance in temperate climates where precipitation exceeds evapotranspiration which can result in high $\mathrm{N}$ losses due to leaching (Neumann et al. 2007).

In cereal-legume mixtures $\mathrm{N}$ losses due to leaching were significantly reduced even at high legume densities 
(Hauggaard-Nielsen et al. 2003; Szumigalski and Van Acker 2006; Neumann et al. 2007; Pappa et al. 2011). Although $\mathrm{N}$ leaching was found to decrease in pea-barley intercrops compared to sole crops, these results were not significant (Hauggaard-Nielsen et al. 2001b). Positive effects have also been observed when incorporating grasses into cropping systems as catch crops or green manure leys, reducing the risk of $\mathrm{N}$ losses during the winter season (Hauggaard-Nielsen et al. 2009; Dahlin and Stenberg 2010). However, greater N mineralisation rates were found after winter, and $\mathrm{N}$ taken up by catch crops may still be lost if it remineralises before the main crop can take it up (van Dam 2006). Subsequent fertiliser application coinciding with $\mathrm{N}$ release through remineralisation can increase $\mathrm{N}$ losses from the system through leaching (Whitmore and Schröder 2007). Hence, it is important to understand the timing at which $\mathrm{N}$ is released by the intercrops (Whitmore and Schröder 2007) and to select appropriate cultivars (Pappa et al. 2011). Pappa et al. (2011) found that nitrous oxide emissions differed significantly between different pea cultivars within pea-barley intercrops, and could potentially exceed total $\mathrm{N}$ losses compared to monocrops.

The 'safety net hypothesis' refers to the ability of deep rooted plants in agroecosystems to capture nutrients from deeper soil layers and the subsoil, thus reducing the risk of $\mathrm{N}$ leaching in such systems (Van Noordwijk et al. 1996). Such effects were tested in two different soil types, a sandy soil and a clay loam (Bergeron et al. 2011). The hypothesis was found to be true in two separate studies, where $\mathrm{N}$ losses could be significantly reduced in a clay loam (Bergeron et al. 2011; Wang et al. 2011), but not in a sandy soil where leaching rates exceeded $\mathrm{N}$ uptake; although sodium leaching was reduced where tree roots were present (Bergeron et al. 2011). Apart from a deeper root system, reduced $\mathrm{N}$ inputs and reduced lateral surface flow reduce $\mathrm{N}$ losses in agroforestry systems (Wang et al. 2011).

Complementarity in root development and rhizospheremediated processes, coupled to nutrient cycling can thus operate synergistically to enable facilitative processes to increase crop growth in multi-cropping circumstances (Fig. 2).

\section{Suppression of soil-borne diseases and pests}

Crop diseases are predominantly caused by bacteria, actinomycetes and fungi (Brussaard et al. 2007). Cultural management practices, such as multiple-cropping and crop rotations can offer a form of biological disease and pest control (Hao et al. 2010). Crops, when grown in combination with other species, show less reduction in productivity and damage due to pest and disease incidence, than when grown as a sole crop (Trenbath 1993; Eisenhauer 2012).

\section{Soil-borne pathogens}

Cultural practices, which allow the build-up of high pathogen population densities (monocultures), and several abiotic factors, including high levels of soil compaction, poor drainage and low organic matter and nitrogen content, increase the severity of root diseases (Abawi and Widmer 2000). Pathogen development can be controlled by suppressive micro-climatic and soil conditions, and natural enemies and the soil microflora itself (Motisi et al. 2009; Fernández-Aparicio et al. 2010; Abdel-Monaim and Abo-Elyousr 2012). Multiple-crop systems and the cultural management practices alter the above mentioned biotic and abiotic conditions. The mechanisms acting on the suppression of soil-borne pathogens can broadly be grouped into physical, ecological and bio-chemical processes (allelopathy), similar to weed suppression. All controlling mechanisms exploited by multiple-crop systems decrease the population growth rates of the organism(s) by: reducing the host abundance and quality; altering the soil environment; increasing competition between the soil microbes, favouring natural enemies, predators and parasites of the targeted pathogens or pests (natural enemy hypothesis); and/or by interfering directly with host colonisation, growth and reproduction through biochemical means (allelopathy).

Physical barriers and reduced host plant density

Physical barriers preventing inoculum spread are created by intercropping immune non-host species with host plants, further reducing host plant density (Trenbath 1993; Fernández-Aparicio et al. 2010). Pathogens fail to colonise non-host plants and die. Further, the decreased number of host plants per unit area increases the distance between hosts, exerting further stresses on pathogens (Fernández-Aparicio et al. 2010). These effects have been demonstrated in several studies for airborne fungal pathogens (Trenbath 1993; Wolfe 2000) and viruses (Altieri 1995b). However, exact mechanisms are difficult to identify belowground due to a complex array of plant-soil-microbial interactions. 


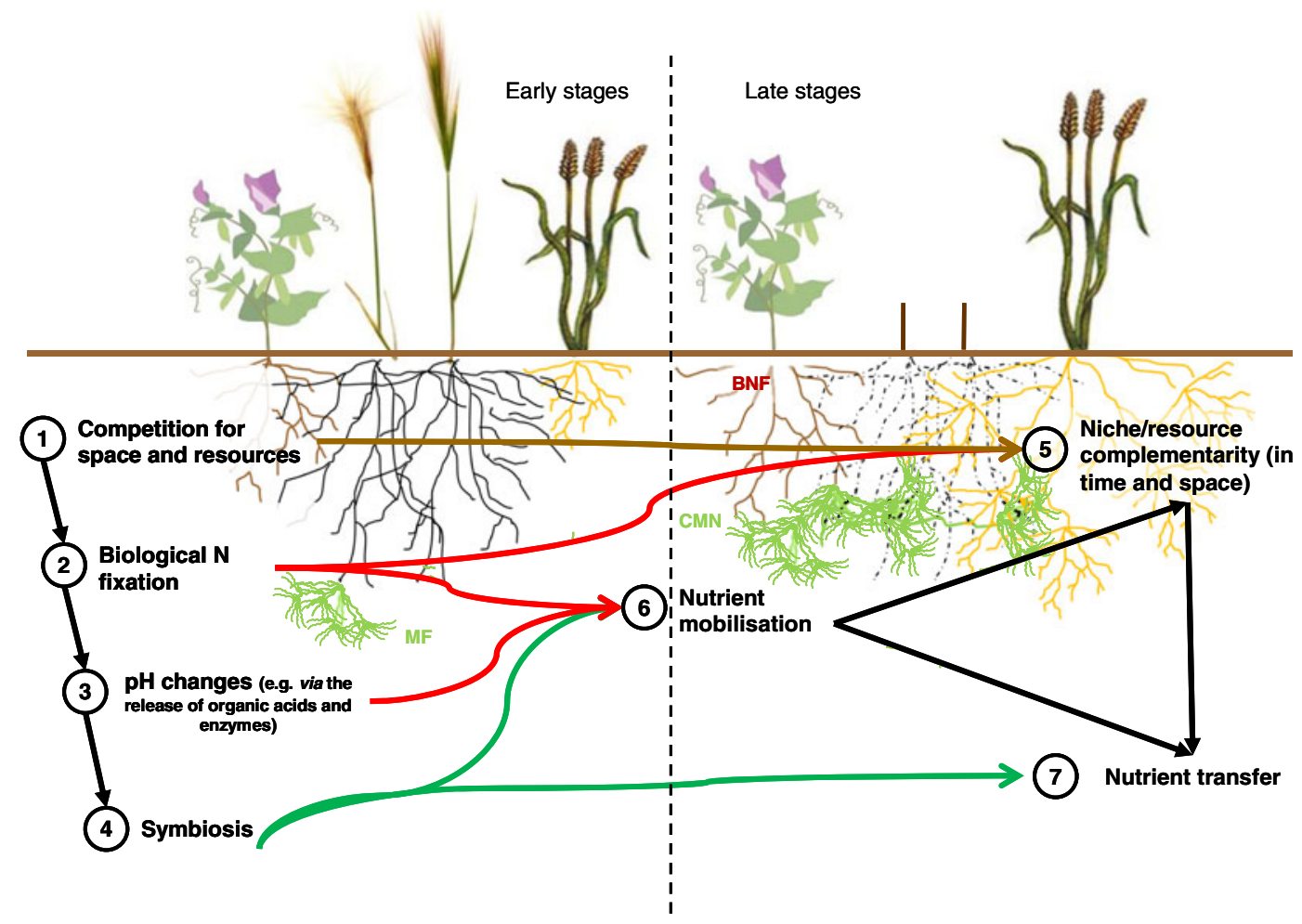

Fig. 2 Root development, nutrient dynamics and rhizosphere processes in arable multi-cropping production systems enable facilitative processes during later plant development stages (theoretical example of a pea, wheat, maize intercrop). Early interplant competitive pressures enable facilitation in the later stages of plant development. Black arrows indicate interconnections and direction of support/enhancement in downward order, arrows represent physical (brown), bio-chemical (red; e.g. biological $\mathrm{N}$ fixation (BNF)), and ecological rhizosphere processes which enable direct and indirect resource facilitation (green; e.g. root colonisation by mycorrhizal fungi (MF) and common mycorrhizal networks $(\mathrm{CMN})$. (1) Interspecific competition promotes root growth. Early root development determines the spaces and volumes of soil occupied. (2) Soil N depletion by wheat, increases biological nitrogen fixation (BNF). (3) plants have different mechanisms by which rhizosphere $\mathrm{pH}$ levels are altered and nutrients mobilised. (4) Competitive pressures and host plant diversity encourage col-

Natural enemy hypothesis

The natural enemy hypothesis, states that the low incidence of disease and pests in intercrops is likely due to higher abundance of their predators, antagonists and parasites in diverse cropping systems. No apparent experimental data is available on whether increased microbial biomass in multiple crop systems has a positive effect on pathogen suppression through predation. Root exudates and their more complex secondary compounds attract a onisation by mycorrhizal fungi (MF), through which plants can access greater soil nutrient and water pools in exchange for carbon. (5) Root systems may be complementary in architecture (e.g. tap roots vs. other roots) and spaces occupied, or essentially may occupy the same space over time, such as maize, which recovers once wheat has been harvested, and extra nutrients are mobilized. Through BNF legumes and cereals utilize different pools of nitrogen. While cereals deplete soil N pools, legumes rely on atmospherically fixed N. (6) In intercrops plants can use different mechanisms to utilize different soil P forms and sources, which ultimately leads to nutrient complementarity and transfer. (7) Nutrient transfer may occur directly or indirectly, over time and space. Excess nutrients via BNF or mobilisation may be transferred to neighbouring plants directly (if rhizospheres can interfere), or indirectly, via common mycorrhizal networks (CMN). Upon plant decay excess nutrients become available and are transferred via said mechanisms

diverse range of antagonistic microbes (Liebman 1995; Motisi et al. 2009; Hao et al. 2010), which can control pathogen populations via predation and/or parasitism, or competition, leading to niche exclusion and the production of antibiotics (Altieri 1995c). Studies have found significant relationships between soil microbial diversity and disease suppression of $R$. solani, Bacillus bacteria, but less so for actinomycetes (Brussaard et al. 2007).

However, the complexity of the soil food web and the interactions with abiotic factors make it impossible to 
predict the distribution and composition of microbes associated with certain crop combinations, hence significant disease suppression need not necessarily occur.

\section{Allelopathy}

Many plant species resist pathogen attack by releasing allelochemicals into the rhizosphere (Liebman 1995; Hao et al. 2010). By intercropping allelopathic nonhost species farming systems can provide cross-disease defence between the component crops, where antagonistic secondary metabolites released by one plant root can effectively suppress the pathogen of another plant (Hao et al. 2010).

Several species of alliums, vegetables and herbs have been reported to suppress pathogenic microorganisms by means of allelopathic root exudates, either when intercropped or when residues are incorporated into the soil (Hao et al. 2010; Abdel-Monaim and Abo-Elyousr 2012). Damping-off and root rot, caused by several fungi (R. solani, Fusarium spp, Macrophomina phaseolina, Sclerotinia sclerotiorum), cause severe damage to agricultural crops, such as bean, lupines and lentil (Lens culinaris). In greenhouse and field experiments, AbdelMonaim and Abo-Elyousr (2012) showed that intercropping cumin (Cuminum cyminum), anise (Pimpinella anisum), onion (Allium cepa) and garlic with lentil decreased damping-off and root rot diseases in lentil significantly. Some cereals, such as maize, wheat, barley and rice (Oryza sativa) have also been shown to release antimicrobial root exudates. These crops are resistant to, and can prevent, root and stem rot disease caused by Fusarium oxysporum even in the following crop (Hao et al. 2010; Abdel-Monaim and Abo-Elyousr 2012).

\section{Biofumigation}

Biofumigation ultimately represents a form of allelopathic defence mechanism with the ability to suppress fungal pathogens, parasitic nematodes and weeds (Abawi and Widmer 2000; Mattner et al. 2008). Brassica species produce glucosinolates (GSLs), which upon hydrolysis by enzymes produced by soil microbes (e.g. myrosinase) produce toxic isothiocyanates (ITC) and nitriles (Halbrendt 1996; Mattner et al. 2008; Motisi et al. 2009). The active toxins are generally only produced when plant tissue is damaged and decomposition processes occur (Mattner et al. 2008). Kirkegaard and Sarwar (1998) found that root biomass contains much higher levels of ITC. These compounds apparently stayed active in the soil for some weeks (Mattner et al. 2008). Hence, biofumigation as a means for disease and pest control is likely only feasible in relay-cropping scenarios and not in intercrops as such.

Hauggaard-Nielsen and Jensen (2005) state that, although no biofumigation studies including multiple-crop systems were found, such systems may influence the rate of GSL hydrolysis and ITC released, as such processes are influenced by climatic conditions (water stress), nutrient availability, abundance of pest and diseases and interspecific competition, all of which are affected by multi-crop systems. When intercropping mustard and radish (Raphanus sativus) in rotation before sugar beet Motisi et al. (2009) found reductions in $R$. solani pathogen levels in sugar beet, however, reductions have also been observed in intercrops with brassica, and nonbrassica species (Kluth et al. 2010). Direct effects of biofumigation cannot account for the overall level in disease reductions. Changes in microbial structure, and increased antagonism/competition, also play an important role in suppressing $R$. solani (Motisi et al. 2009). Such changes may simply be brought upon by increasing the OM content in soil (Mattner et al. 2008). However, due to the generally lesser degree of disinfection, the use of artificial pesticides may not be eliminated completely but can be significantly reduced (Halbrendt 1996; Mattner et al. 2008).

Plant-growth-promoting rhizobacteria (PGPR)

Endo- and epi-phytic rhizobacteria, such as Herbaspirillum, but also AM fungi, can benefit a host plant by promoting plant growth via biological $\mathrm{N}$ fixation, nutrient solubilisation, synthesis of hormones and vitamins, by biological disease control, and via inducing systemic resistance (Altieri 1995c; Eisenhauer 2012; Monteiro et al. 2012). In most cases, biological control results from bacterial production of metabolites, such as antibiotics and hydrogen cyanide, which directly inhibit the pathogen, (Kloepper et al. 1999). Among the soilborne pathogens negatively affected by root colonising rhizobacteria are $R$. solani and F. oxysporum. Disease suppressing effects may spread onto neighbouring plants if roots intermingle freely, although this has not been verified. It has been shown that species-rich grasslands and pastures harbour higher levels of PGPR than homogenous grasslands (Eisenhauer 2012). Some cropassociated PGPR and AMF can activate a host plants 
chemical and/or physical defence mechanisms (Kloepper et al. 1999; Eisenhauer 2012; Monteiro et al. 2012). This behaviour is termed induced systemic resistance, where the associated rhizobacteria or mycorrhizal fungi act as an inducer. Bacterial inducers have been added to experimental plots (Kloepper et al. 1999; Monteiro et al. 2012), but may also be attracted by component crops in crop rotations or intercropping scenarios. Specific studies are yet to be carried out. The effects of AM fungi on pathogen suppression are complex and poorly understood, but generally beneficial, although in some cases (e.g. Phytophtora root rot in soybean) can be detrimental (Altieri 1995c).

\section{Parasitic nematodes}

Few published studies have focussed on the effects of intercropping on pest nematodes (e.g. Halbrendt 1996). The mechanisms involved in controlling nematode attacks via intercropping are the same as for disease suppression. Some allelopathic and biofumigant crop species, such as marigold (Tagetes spp.) and Solanum sisymbriifolium (sticky nightshade) can produce nematicidal chemical compounds (Altieri 1995b; Halbrendt 1996; Dias et al. 2012). Through intercropping, it is possible to exploit allelochemical effects and reduce the host plant densities within the field (Liebman 1995; Halbrendt 1996). Crop rotation in contrast, is not a very successful practice, due to the large host range of some nematodes (Abawi and Widmer 2000). The same suppressive mechanisms and environmental conditions affecting pathogens affect the growth and survival of nematodes (Halbrendt 1996; Kloepper et al. 1999). Although greenhouse experiments have produced promising results in reducing numbers of nematodes by biological means, there are few reports of successful implementation in large-scale agriculture (Halbrendt 1996), as the dominant limiting environmental factors vary heavily (Trenbath 1993).

Several brassica species, Sudangrass (Sorghum spp.), marigold and some tropical legumes, such as velvet bean (Mucuna deeringiana), are beneficial component crop species, with high nematodal suppressive potential through the production of biofumigant secondary metabolites and partly through stimulation of antagonistic microorganisms (Liebman 1995; Halbrendt 1996; Kloepper et al. 1999; Abawi and Widmer 2000). Kluth et al. (2010) found that allelopathic traits of mustard and oilseed radish (Raphanus sativus) cultivars when intercropped successfully reduced nematode infestations in the following sugar beet crop, when residues were incorporated into the soil (biofumigation).

In multiple-crop systems, randomly-dispersing root parasitic nematodes can be intercepted by non-host ('trap') crop species or cultivars. Nematode larvae entering non-hosts cannot develop and die (Trenbath 1993). Sudan grass, oats, rye, yellow mustard (Brassica campestris) and oilseed radish are non-hosts (Abawi and Widmer 2000). Intercropping oat with nematode resistant barley reduced the nematode reproduction by $60 \%$ (Trenbath 1993). However, experiments introducing the non-host sainfoin (Onobrychis viciifolia) into American pastures showed no effect on northern root knot nematode populations (Shigaki et al. 1998).

\section{Weed suppression via belowground mechanisms - allelopathy}

In agricultural systems, weeds are essentially plants unwanted in a particular context. Typical arable weeds are pioneer species adapted to colonise disturbed habitats. Following circumstances of repeated herbicide application, the most common weed species have often developed resistance to chemical herbicides (Liebman and Dyck 1993). Due to environmental and human health issues related to the ever increasing use of pesticides, means are sought to reduce the reliance on such products (Bhowmik and Inderjit 2003). One potential means to naturally reduce the spread and density of weed species significantly is intercropping (Liebman and Dyck 1993). Within multiple-crop systems several mechanisms by which weeds are suppressed have been described. Belowground competitive processes by which weedy plants may be outcompeted have frequently been reported in cereal-legume intercrops, and include the rapid exhaustion of existing resources (light, water and nutrients) and niches (Hauggaard-Nielsen et al. 2001b; Singh et al. 2003; Poggio 2005; Zarea et al. 2009). In addition, allelopathic traits of certain crops have the potential to inhibit the growth of weeds (Batish et al. 2001).

Allelopathy is defined as the effects of one plant (including its associated micro-organisms) on neighbouring plants via the exudation of chemical compounds into the environment. A multitude of allelochemicals have been identified, and they can be classed into two major groups: phenolics and terpenoids (Singh et al. 2003). These allelochemicals can have stimulatory and/or inhibitory effects (Rice 1985). Allelopathic processes interact with 
and amongst the biotic (vegetation and the soil biota) and abiotic environment. In order for such traits to be utilised effectively as a means for weed control, allelopathic effects need to be selective, i.e. weed species must be more susceptible to such substances than the associated component crop(s) (Singh et al. 2003).

Allelopathic interactions in multiple-crop systems can also be induced once incorporated into the soil in the form of cover, smother, and green manure crops in relay cropping systems, where decomposition processes and microbes can release weed inhibiting substances into the soil. Plant residues incorporated into the soil are considered less effective as living mulches in suppressing weeds, as living mulches can add to the inhibiting effects of allelochemicals by actively competing with weeds for resources. Furthermore, the effect of crop residues typically decreases after some weeks due to the breakdown of allelochemicals by the soil biota (Abawi and Widmer 2000; Singh et al. 2003).

In field experiments it is difficult to unequivocally distinguish between resource competition, allelopathy, nutrient immobilisation and microbial influences (Liebman and Dyck 1993). Furthermore, the release and concentrations of allelochemicals are affected by environmental conditions. Abiotic and biotic stresses, such as temperature, soil moisture and $\mathrm{pH}$, and the presence and abundance of pests, trigger the release of allelochemicals into the environment and influence their concentrations (Inderjit 2001). In addition, soil microbes transform allelochemicals through metabolic processes (Blum et al. 1999; Pellissier and Souto 1999; Bhowmik and Inderjit 2003) and so affect the growth and distribution of crops and weeds alike. Crops with allelopathic traits capable of suppressing weeds may be directly intercropped, or included into crop rotations. These techniques however require a change in system and the complex interactions make the outcome difficult to predict. Hence, most research has focused on extracting and synthesising the active weed inhibiting compounds to produce natural herbicides, which then can be applied onto fields (Fujii 2001; Singh et al. 2003; Hooper et al. 2009).

Several studies have detected weed suppressing potential in common crops and pasture species, owing to allelopathic qualities (Singh et al. 2003). The list contains cultivars of common leguminous, graminaceous and brassica crop species, and species such as rye (Batish et al. 2001; Fujii 2001; Bhowmik and Inderjit 2003; Singh et al. 2003) and nearly 80 tree species
(Rizvi et al. 1999). Lemerle et al. (2001) studied the effects of several wheat varieties on perennial ryegrass (Lolium perenne) and found that negative effects on the weed were partly due to environmental conditions but also due to genotype, and individual weed inhibiting traits. The structure of weed communities is also altered by intercropping. In barley-pea intercrops Mohler and Liebman (1987) found that as crop seed production increased, total weed biomass and the relative importance of dominant weed species decreased.

Due to the intensive breeding of crops to produce high yielding varieties, the allelopathic potential, and thus the plants' natural defence mechanisms, have apparently been greatly reduced (Lovett 1982; Halbrendt 1996). Some cultivars of sorghum, wheat, oat (Avena sativa), and barley contain more known allelochemicals than others (e.g. coumaric acid, vanillic acid, and scopoletin). When grown as sole crops in the absence of herbicide application, such traits gave them competitive advantages over cultivars producing less of these substances (Alsaadawi et al. 1986; Halbrendt 1996; Baghestani et al. 1999). These cultivars were able to produce more biomass due to the suppression of weeds and resulting reduction in interplant competition stresses.

Apart from individual genotypes, several crop combinations have been studied for their allelopathic effects on weeds. Negative effects on crop growth caused by the component crops have been observed in intercrop systems (den Hollander et al. 2007), yet it is unclear whether competition, plant physiological or allelopathic traits were the limiting factors. Studies by Fleck et al. (1984), in which intercrops of maize-bean and maize-sunflower were investigated, suggest that as well as increased crop density, species richness may also have suppressive effects on weeds, i.e. not only the competitive behaviour of mixed cropping systems, but also allelopathic effects of individual crops may be the cause for weed suppression. Although canopy height and soil cover development (light competition) were found to be the dominant factors in suppressing weeds, in some cases allelopathy was identified as the cause for weed suppression (Liebman and Dyck 1993; Bhowmik and Inderjit 2003; den Hollander et al. 2007). However, negative examples (barley-pea, with mustard as the weedy plant), where mixed cropping has failed to reduce weed growth to the same extent as barley sole-crop, which was a more weed suppressive crop, have also been reported (Liebman and Dyck 1993). 
The release of phytotoxins and the production of phytotoxic microbial products effectively reduced the presence of several common weed species when residues were incorporated into the soil using cover crops, such as rye, wheat, sorghum and barley, and/or when intercropping several oat varieties, or clover and/or Italian ryegrass into cereal, faba bean or pasture systems (Dyke and Barnard 1976; Putnam et al. 1983; Bhowmik and Inderjit 2003). Allelochemicals were shown to be even more effective than herbicides when clover was incorporated as dead mulch (Liebman and Dyck 1993).

Trap crops, are plants grown to attract a certain agricultural pest away from the main crop. Common crops, such as durum wheat, oat, sorghum and fenugreek (Trigonella foenum-graecum) can be intercropped successfully to inhibit broomrape (Orobanche) and witches weed (Striga) species in grain and forage legumes without compromising the growth of the component crop (Lins et al. 2006; Fernández-Aparicio et al. 2008; Hooper et al. 2009; Fernández-Aparicio et al. 2010; Fernández-Aparicio and Rubiales 2012). The component crops can inhibit broomrape germination and/or trigger seed germination of said parasitic weeds leading to 'suicidal' germination.

Thus although several mechanisms and plant characteristics can be exploited for weed suppression in multiple-crop systems, allelochemicals play a significant role in mutualistic or hostile plant-plant and plantsoil communication and interactions, and require further investigation as to how and when such chemicals are released. Perhaps related to the monotonouscompound model for many chemical-based crop protection approaches, there appears to have a focus on the action of individual allelochemicals.

In summary, a range of ecological, biochemical and physical mechanisms operate belowground in multicropping systems to effect soil-borne pest, disease and weed suppression (Fig. 3).

\section{Soil biotic community composition and structure}

The highest species diversity in agricultural systems is found in the soil (Brussaard et al. 2007). In agricultural systems, the diversity within the soil microbial communities can be termed 'unplanned diversity' and can only be managed indirectly (Brussaard et al. 2007), although inoculation can introduce certain functional groups to enhance desirable soil functions (Zarea et al. 2009), albeit often in a non-persistent manner. Soil biodiversity in crop systems is the result of complex interactions between the planned aboveground diversity and the niches created through cultivation practices and rhizosphere processes. Functional diversity plays an important role in soil functioning (George et al. 2012), including resilience towards stress, disturbance and disease, and the efficient use of resources, via interactions with rhizosphere processes that are important for plant growth, such as $\mathrm{N}$-fixation, $\mathrm{P}$ mobilisation and facilitation, nutrient and water uptake via mycorrhizal fungi, and soil structural dynamics (Zhang et al. 2004; Ritz 2006; Song et al. 2007a).

Plants provide energy sources for soil microbes. In general, soil nutrient content, enzyme activity and microbial biomass are higher under multiple-crop systems than under monoculture (Zhou et al. 2011), especially when trees were intercropped (Farrell and Altieri 1995). Through differences in the amount and composition of root exudates, plants can exert species specific effects on rhizosphere microbial communities, depending on their nutrient demands and capacity to decompose substrates (Song et al. 2007a). Some plant specificity is also expressed through symbiotic and parasitic relationships (e.g. plant growth-promoting rhizobacteria (PGPR), rhizobia, mycorrhiza). However, other edaphic factors can have an overriding effect. Microbial community composition is mainly affected by physical and chemical soil characteristics, as opposed to type and source of inocula (Griffiths et al. 2008a), or host plant (Song et al. 2007b). In contrast, host plants rather than chemical soil properties were found to have stronger effects on mycorrhizal fungi community structure (Bainard et al. 2012). Possibly due to some degree of host specificity by mycorrhizas and the fact that some plant species do not associate with arbuscular mycorrhizal fungi (AMF), but ectomycorrhizas, and vice versa (Bever et al. 2010). Such host specificity and the presence and composition of microbial soil communities, also affects plant-plant interactions via resource partitioning, resource sharing via common mycorrhizal networks (CMNs) (source-sink relationships), and feedback systems via trophic interactions (Bever et al. 2010). The roots in multiple-crop systems are in direct contact and interact, and thus alter chemical soil properties via changes in nutrient content and root exudates (Song et al. 2007a; Zhang et al. 2010a). 


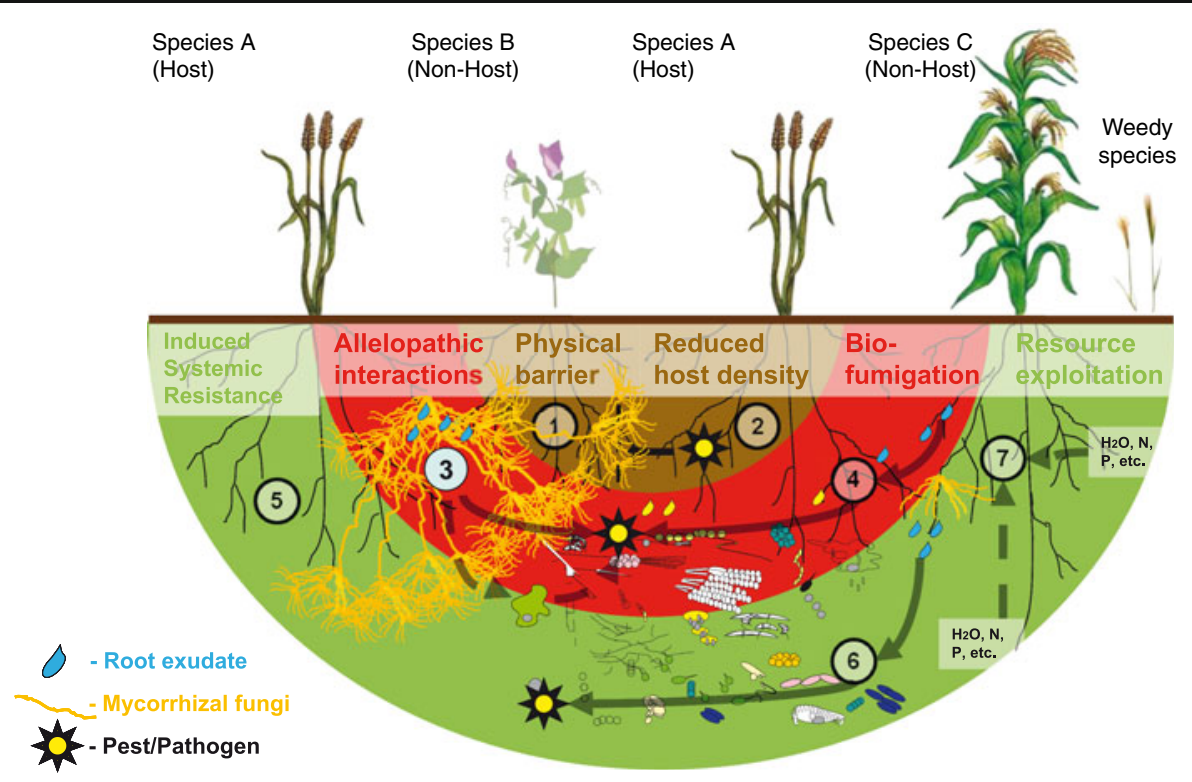

Fig. 3 Belowground mechanisms for soil-borne disease, pest and weed suppression as have been demonstrated in multiplecrop production systems. This diagram illustrates the ecological (denoted in green sector in figure), biochemical (red) and physical (brown) mechanisms involved in the plants natural defence mechanisms, which are enhanced with increasing diversity within the system. (1) Non-host species intercropped can form physical barriers, which inhibit pathogens and pest to infest neighbouring host plants; (2) Intercropping reduces the host plant density significantly reducing the severity of disease/pest infestations; (3) Roots exude allelochemicals which directly, or

\section{Enzyme activity}

Intercropping as opposed to sole crop rotations, was found to significantly increase a wide range of enzyme activities, in turn related to crop growth (Zhang et al. 2010b; Zhou et al. 2011). Higher enzyme activities in mixed clover pastures were related to higher OM inputs, AMF mycelium decomposition and differing root growth parameters between clover species (Zarea et al. 2011). Increased root exudation and earthworm populations, due to their biotic effects on soil structure, in multiple-crop systems, were suggested to provide conditions outside the rhizosphere conducive to nitrogenase activity by free-living bacteria (Zarea et al. 2009).

\section{Bacteria}

Bacterial communities in multiple-crop systems have mainly been studied in an arable context. Bacterial community composition in these circumstances is through microbial metabolic processes are transformed to inhibit the growth of selective other plant species, and pathogenic microbes; (4) biofumigant compounds, e.g. from brassicas such as glucosilonates are transformed to isothiocyanides and nitriles; (5) Pathogen attack and mycorrhizal connections can induce systemic resistance, and boost the plants own natural defence mechanisms; (6) Greater quantities and ranges of root exudates attracts beneficial microbes, including natural enemies and parasites to pathogens; (7) Resource complementarity and more efficient resource use in intercrops can suppress weed infestations

affected by a range of soil chemical and biological properties, such as iron nutritional status of the plant, manganese availability, soil type, plant species, and plant associated organic acid composition of root exudates, and mycorrhizal colonisation (Song et al. 2007a; Zhang et al. 2010a). Although, on a global scale soil $\mathrm{pH}$ apparently strongly influences bacterial diversity (Fierer and Jackson 2006), Zhang et al. (2010a) found little effect of soil $\mathrm{pH}$ on bacterial community composition at field scale. While soils can override plant effects on bacterial community composition in monocrops (Song et al. 2007a), studies have found plant diversity to be the main determining factor, but mainly affected microbial biomass and activity, rather than community composition (Manna and Singh 2001; Qiao et al. 2012).

Given that rhizosphere bacterial communities are plant dependent, it would be hypothesised that bacterial communities would differ between different crop species. Qiao et al. (2012) found clear distinctions between 
the rhizosphere communities of oat and common vetch (Vicia sativa) grown in the same soil. However, Song et al. (2007b) found that rhizosphere communities of wheat, maize and faba bean did not differ, and were more affected by the soil type rather than plant species. But when intercropped, significant differences in community composition were found between the wheat-faba bean and wheat-maize intercrops, and compared to their sole crops (Song et al. 2007b). Bacterial diversity was found to be higher in crop mixtures although evenness was equal to sole crops (Song et al. 2007b; Qiao et al. 2012), with some new species found in mixtures, which were not present in monocultures (Zhang et al. 2010a), suggesting that new plant chemicals are being produced in intercrops (Zhang et al. 2010a; Qiao et al. 2012), or a generally greater range and/or greater amounts of combined root exudates result from intercropping (Zarea et al. 2009). For example, the different composition of inorganic and organic acid compounds released by roots in a wheat-maize intercrop may affect acid-sensitive microbes (Zhang et al. 2010a). Although intercropping was found to affect the presence and abundance of certain groups of bacteria, the distribution of the main phylogenetic groups was similar in both, multi- and sole cropping (Zhang et al. 2010a). In mixed pastures, the seeding ratio of berseem clover to Persian clover (Trifolium resupinatum) also affected bacterial diversity and the presence/absence of certain groups (Qiao et al. 2012). In contrast, Zhang et al. (2010a) found highest species richness of bacteria in monocultures and not in faba bean-maize intercrops. Within some agroforestry systems, compared to conventional arable fields, significantly greater Gram-positive to Gram-negative bacteria ratios were found, including beneficial actinomycetes, which are important decomposers and antibiotic producers (Lacombe et al. 2009).

When comparing multi-species arable systems with monocultures, the influence of plant diversity on soil bacterial diversity became more pronounced over time (Song et al. 2007a; Zhou et al. 2011). This may be partly due to differing growth phases, but mainly due to increased root exudation in older plants (Song et al. 2007a). Bacterial responses to increased plant diversity took longer than fungal ones and were more variable (Zhou et al. 2011). Studies suggest that intercropping increases C:N ratios (Song et al. 2007a; Oelbermann and Echarte 2011). However, there was no clear connection between $\mathrm{C}: \mathrm{N}$ ratios and bacterial community composition, but such increased ratios support greater fungal communities (Song et al. 2007a).
Arbuscular-mycorrhizal fungi

Arbuscular-mycorrhizal (AM) fungi are obligate biotrophs, which infect plant roots. In exchange for carbon, AM fungi pass on nutrients such as $\mathrm{P}, \mathrm{Fe}, \mathrm{Zn}$ to the colonised root. Such relationships are mainly mutualistic, but can also be parasitic, depending on the fungal species and host plant involved (Klironomos 2003). Most studies on AMF in multi-cropping circumstances have focussed on alley cropping designs. The inclusion of tree species can alter microbial communities by modifying the microclimate within the cropping alleys, improving soil structural stability via roots and extraradical mycelium networks and different organic matter inputs, and by nature of the more heterogeneous vegetation cover can affect soil chemical and nutritional properties, via patchier distribution of leaf litter and root networks (Chifflot et al. 2009; Lacombe et al. 2009; Bainard et al. 2011a).

In contrast to bacteria, AM fungi were found to be more affected by host plant abundance and diversity, rather than soil chemical properties (Bainard et al. 2012), apart from nutrient availability (Lacombe et al. 2009). Strong host specificity amongst mycorrhizal fungi leads to distinct plant-specific fungal communities, with some species exclusively associated with arbuscular, ecto-, or ectoendo-mycorrhizal fungi (Bever et al. 2010; Bainard et al. 2011b). Increasing plant diversity has been shown to have positive effects on AMF diversity, community composition and sporulation (Bainard et al. 2011a). Significant losses in AM fungal diversity in agricultural soils are likely to be caused by fertilisation, fungicide application, intensive soil disturbance regimes, and low host diversity (Chifflot et al. 2009; Lacombe et al. 2009; Bainard et al. 2011b). Even within diverse agricultural systems, the effects of fertiliser application may mask the effects of greater host plant diversity and density, resulting in the selection of specialised microbial communities (Lacombe et al. 2009).

Conventional farming systems tend to harbour AM species that are able to tolerate high levels of nutrients and may be dominated by one single species (Chifflot et al. 2009). In agroforestry systems, tree roots providing constant AM inocula to successive intercrops could counter these negative effects. Compared to conventional crop systems, the fungi found in agroforestry systems do not differ significantly, although the number of AMF taxa and the species diversity within these taxa were significantly higher (Bainard et al. 2011b; Bainard et al. 
2012). Increased biomass and diversity amongst microbial communities in TBIs is spatially related to the tree rows and less to the arable intercrops (Bainard et al. 2012), and depending on management intensity and tree density, the transfer of tree AMF to crops, stimulating crop growth in the centre of the alleys may take several years (Chifflot et al. 2009; Bainard et al. 2011a).

In a two-clover species pasture system, Zarea et al. (2009) tested feedback systems within diverse pastures by hypothesising that the ratio between berseem clover and Persian clover, affects AMF colonisation, which in turn affects $\mathrm{N}$ uptake and thus productivity of the pasture system. Mycorrhizal colonisation rates were affected by and increased due to increased plant organic carbon inputs from the multi-crop clover system (via root exudation), and carbon inputs into the system were found to be affected by the ratio of berseem clover to Persian clover. Increased AMF colonisation increased $\mathrm{N}, \mathrm{P}$ and $\mathrm{Zn}$ uptake, promoting plant growth, thus further increasing root exudation, supporting larger soil microbial communities (Zarea et al. 2009).

\section{Invertebrates/earthworms}

In many agricultural landscapes, earthworms provide a range of beneficial roles, including increased mineralisation of organic matter, generation and stabilisation of soil structure, stimulation of general microbial activity, control of pests and parasites, and the stimulation of symbionts (Reddell and Spain 1991; Zarea et al. 2009). In arable soils earthworm populations are mainly affected by the quality (nutritional value) and amounts of organic matter inputs, and nature of the prevailing tillage system (Schmidt and Curry 2001).

In agroforestry systems higher earthworm abundance was measured near tree rows (Thevathasan et al. 2004), which represent undisturbed habitats with higher SOC contents. In a wheat-clover intercropping system, with constant clover cover, Schmidt and Curry (2001) found the absence of tillage but particularly a constant supply of nitrogen rich plant residues to be beneficial to earthworm populations. Compared to conventional agriculture, after several years of intercropping clover into wheat, rye or sorghum, the high levels of earthworm biomass found were more comparable to pastures and

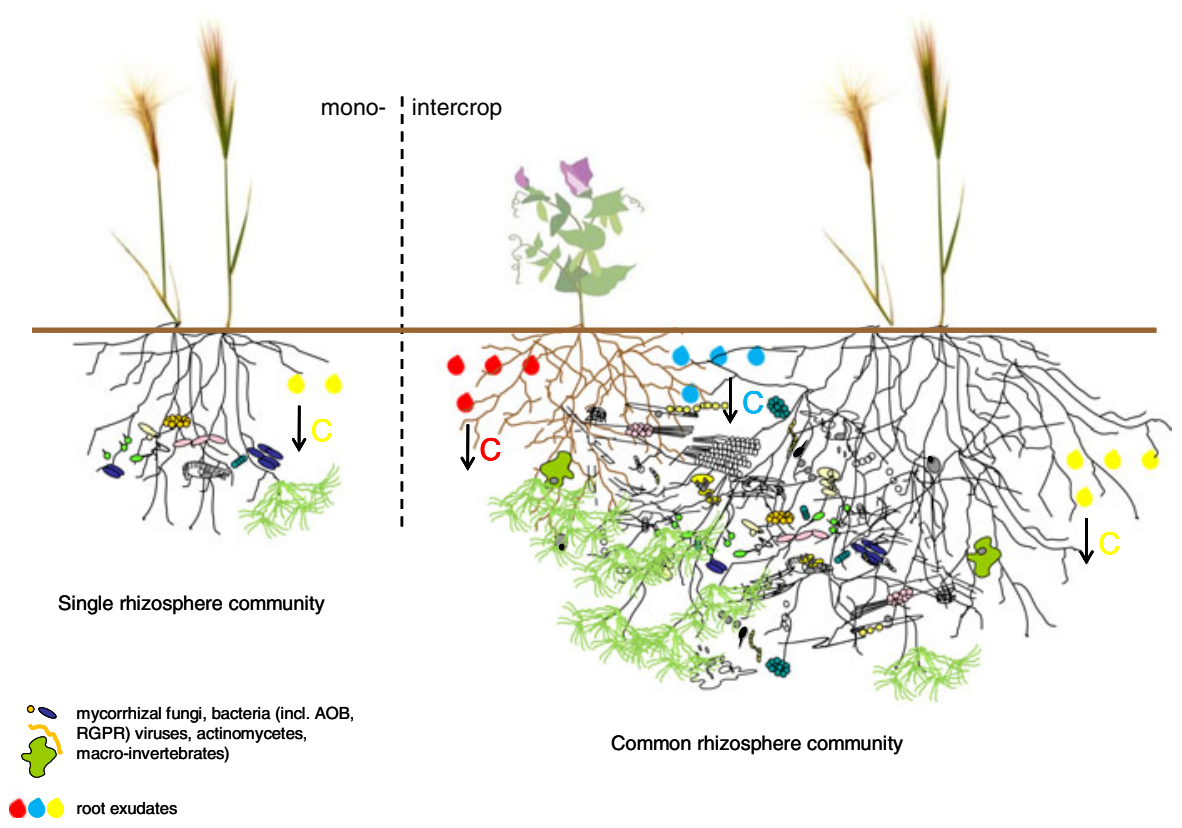

Fig. 4 Interspecific competitive mechanisms which affect associated rhizosphere communities in multiple crop systems. Biotic factors include greater amount and diversity of SOM inputs via roots, leaf litter; new, and greater range and amount of root exudates and associated carbon (C) due to increased root networks and competitive interactions; attraction of greater populations and diversity of soil organisms. Abiotic factors include modulation of physical and chemical soil properties (porosity, $\mathrm{pH}$, etc.); microclimate; soil cultivation practices, tillage, fertiliser and pesticide application rates (the latter are not necessarily affected by multi-cropping practices as such, but can override such effects) 
perennial grassland habitats. Similarly, in pastures containing red and white clover up to three times larger earthworm populations were found compared to cloverless pastures (Sears and Evans 1953).

Apart from increasing earthworm abundance, species richness is also increased by supporting a more favourable habitat due to intercropping wheat with clover. Schmidt et al. (2001) found between one and five more epigeic earthworm species in intercrops. However, no significant differences in endogeic earthworm communities were found between conventional and intercropped wheat systems (Schmidt et al. 2001).

Although earthworm habitats and their beneficial impacts on soil structure have long been reported, little is known of how earthworms may also increase plant root exudates creating more microhabitats for microorganisms and stimulate microbial activities (Gange 1993; Zarea et al. 2009). AM dispersal is also manifest by earthworms. It has been observed that endogeic and epigeic earthworm casts carry relatively high concentrations of viable AM propagules, compared to the surrounding soil (Reddell and Spain 1991; Zarea et al. 2009).

Thus the effects of multi-cropping circumstances on the soil biota are complex (Fig. 4) and apparently often context-dependent. This is expected given the complexity of belowground communities, but it remains unclear how idiosyncratic such relationships are, or whether more or less predicable responses arise in particular circumstances.

\section{Soil structure}

Soil structural maintenance in agricultural systems, is not only important in supporting and ensuring continuous agricultural production, but also in regulating water quality and supply, reducing the risk of soil erosion and providing habitat, and supporting belowground diversity (Kibblewhite et al. 2008). There are to date very few research publications reporting direct effects of multiplecrop systems on soil structural dynamics, such as aggregate sizes or stability or porosity, and how these differ from monoculture systems. However, on the basis of findings of other effects of multiple-crop systems on the plant-soil system and biotic functions in soil structural dynamics, such effects can be hypothesised. Indirect evidence is also apparent from studies into intercropping effects on soil erosion processes and OM inputs, especially in agroforestry systems, where significant reductions in run-off rates and the risk of soil erosion have been reported (Wang et al. 2011). Cultural management practices affecting soil structure do not necessarily differ between conventional and multiplecrop systems. Hence, any potential differences in soil structure and quality in multiple-crop systems are likely to be related to its effects on biotic factors and differences in OM inputs. The soil biota affects the generation and maintenance of soil structure via the four fundamental mechanisms as follows.

Adhesion of constituents

The excretion of EPS and mucilages by soil microbes, roots and earthworm gut mucus can bind together soil particles through adsorption to minerals via electrostatic bonds (Chenu and Cosentino 2011). These substances play important roles in soil aggregate stability. As microbial taxonomy does not affect the amounts of EPS produced (Chenu 1995), the differences in soil microbial community structure between conventional and multicropping systems do not necessarily lead to differences in aggregate stability. However, in multiple-crop systems, due to increased interplant competition, increases in the number and length of roots formed, resulting in an increased rhizosphere, can increase the abundance of soil microbes and hence the release of EPS. The production of EPS is generally stimulated by excess C (Kumar et al. 2007). Mycorrhizal fungi also exude extracellular proteins, such as glomalin, which also influence soil aggregate stability (Treseder and Turner 2007).

\section{Surface coating phenomena}

Hydrophobic compounds (e.g. glomalin-related soil proteins and extracellular lipids) that coat the surfaces and pores of soil aggregates reduce the constant drying and wetting and thus reduce incidences of slaking. The release of such substances has been related to aggregate stability, although the mechanisms involved remain unclear. Fungi generally produce more hydrophobic compounds than bacteria, although the amount and type vary amongst different groups of fungi (Chenu and Cosentino 2011).

\section{Binding via filamentous structures}

Soil particles and aggregates are enmeshed by networks of fungal hyphae and by plant roots (Tisdall and Oades 
1983), which can be supplemented by adhesion to soil particles by EPS. Compared to conventional agricultural systems, multi-cropping systems exert more competitive stresses on the component crops, thus increasing their root networks and mycorrhizal connections, in order to access more resources from a greater soil volume occupied. This has ramifications on soil structural dynamics, increasing enmeshment by fungal hyphae and fine roots. In general, fungi have a larger impact on soil structural dynamics and aggregate stabilisation than bacteria (Chenu and Cosentino 2011). This can be explained by the variety of mechanisms by which fungi are associated with soil aggregation and structure. Fungi are involved in all of the above mentioned mechanisms, at a range of spatial scales (Ritz and Young 2004). As discussed above, multiple crop systems typically increase the fungal:bacterial ratio, and hence likely supporting more groups of hydrophobically active microorganisms. The beneficial properties of trees on soil structure have long been recognised (Farrell and Altieri 1995). In multiplecrop systems, especially agroforestry, the abundance of AMF increases, due to the constant presence of tree rows (representing mechanically undisturbed areas) and increased nutrient pressures, forcing crop species to form more symbiotic relationships with AMF. Rillig and Mummey (2006) suggest that interactions between annual and perennial crop species in agroforestry systems can have significant effects on soil aggregate stability due to higher concentrations of EPS and glomalin-related soil proteins. Vice versa, such effects on soil structure can support a wider range and abundance of microbial organisms, thus creating synergies between cropping system, soil microbial communities and soil structure.

\section{Kinetic restructuring}

Kinetic restructuring describes the physical effects that the translocation of soil particles by organisms (bioturbation) can have on pore spaces, particle size distribution and soil aggregates (Bartlett and Ritz 2011). The organisms involved in bioturbation range from micro-scale flora, i.e. protozoa and nematodes, to macro-scale organisms and soft invertebrates. Hence, such processes occur at a range of different scales, depending on the size of the organisms and the amount of soil they are able to move through the soil profile. In temperate agricultural systems earthworms have the largest noticeable impact on soil structural dynamics due to their size and activities (Brown et al. 2000;
Uvarov 2009). Earthworm burrows, root growth and fungal development also create channels within the solid phase of the soil system, increasing pore spaces and drainage within the soil system (Bartlett and Ritz 2011). As discussed above, earthworm community structure and abundance increases significantly in some multi-crop arrangements. Plant roots also restructure soil particle arrangements as they grow (Pierret et al. 2011). In the short term, plants have greater impacts on soil structural dynamics than earthworms (Griffiths et al. 2008b). Plant roots further affect soil structural dynamics via root exudation (e.g. EPS), which can affect soil binding and adhesion (soil aggregation) directly or indirectly via microbial activity; and water uptake, which affects slaking (Materechera et al. 1994; Angers and Caron 1998; Pierret et al. 2011). Such processes result in general packing effects around the roots (Clemente et al. 2005), which are involved in the formation of macropores (Young et al. 1998), especially when deeprooted species are grown. Multiple-crop systems can incorporate a range of differing root networks and structures, generally increasing depths and overall rootlength densities, compared to sole crops. As root networks increase and complementarities among root systems are promoted, the effects root networks have on soil structural dynamics are enhanced in multiple-crop systems.

\section{Other considerations regarding belowground interactions and multi-cropping}

Below-ground interactions affect multiple-crop systems in far more complex ways than conventional sole-crop systems. To maintain or increase productivity while also increasing the beneficial effects on soil functions provided, research should aim to develop best-practice guidelines, in terms of optimal plant combinations and densities for different crop mixtures. This can optimise plant growth benefits by reducing interplant competition while allowing for beneficial interactions in combined rhizospheres, which regulate the main processes involved in nutrient uptake, transfer and facilitation. Some published work has assessed the yield effects of certain crop combinations, row spacing and widths (e.g. two rows of Crop A versus 3 rows of Crop B, etc.), but overall conclusions and recommendations are yet to be drawn, especially for temperate systems (ICRISAT 1981). The ideal ratios in variety mixtures, or when service plants are intercropped 
with crops, as tested for clover mixtures by Zarea et al. (2009) and Qiao et al. (2012) are still largely unexplored and could offer significant information on maximising the efficiency and outputs of multiple-crop systems with respect to a range of management targets (e.g. overall yield, nutrient supply, belowground weed, pest and disease suppression, beneficial belowground microbial interactions). Furthermore, with the development of new crop mixtures their compatibility (e.g. allelopathically) with existing genotypes needs to be assessed when grown in mixtures.

\section{Soil organic matter (SOM)}

In plant-soil systems, SOM inputs are produced by the system and, upon incorporation of OM, interact and affect all the physical, chemical and biological soil processes discussed above, which affect plant growth and development. SOM is also closely linked to SOC, soil fertility, and water holding capacity. All of the biotic processes in the soil system, including ones associated with soil structural dynamics require the provision of energy to the biota in order to be manifest. Energy supply within the soil system is linked to SOM content, vegetation and SOM management. Hence, there is a positive relationship between SOM and soil structure (Magdoff 1995). The management of SOM in intercropping can differ from conventional agriculture, due to the more heterogeneous nature of the residues and plant material produced.

Incorporating trees into agroecosystems creates conditions for a range of microflora and fauna, insects and earthworms that enhance the decomposition and incorporation of organic matter into the soil, by reducing soil losses, evapotranspiration and wind, but also add organic matter via leaf litter, which provides a protective layer (Farrell and Altieri 1995). In multiple-crop systems, especially in agroforestry systems, the composition of OM inputs is more heterogeneous (also spatially), and up to $77 \%$ more SOM may enter, and is stored and cycled in the soil, compared to conventional arable systems (Bambrick et al. 2010).

\section{Crop breeding for multi-cropping}

Crop plant breeding programmes could arguably also target belowground mutualistic and allelopathic traits, to enhance crop productivity at a system level, notwithstanding the technical and logistical challenges this poses. Multi-cropping faces the same issues as organic farming, as both systems still rely on modern crop varieties developed in the context of, and expressly for application in, monocultures targeting a maximised harvestable yield. These are not necessarily the most suitable types for growth when exposed to inter-species competition and different nutrient, and soil-borne pest and disease management regimes (Wolfe et al. 2008).

Positive traits enabling resilience in crops to external biotic (belowground pest and disease attack) and abiotic (temperature, drought, etc.) stresses and resource exploitation under low input or organic systems and adaptations to local environmental conditions, have been replaced with high-yielding varieties. As a result, genetic diversity and local varieties adapted to local belowground selective pressures have disappeared (Altieri 1999; Wolfe et al. 2008). Decentralised and farmer-participatory breeding programmes have yielded positive results, as farmers themselves selected cultivars, which perform most effectively under local conditions, according to personal preference (Ghaouti et al. 2008; Wolfe et al. 2008). Legal issues with using non-commercially available seeds place obstacles in the way of small-scale, decentralised breeding programmes (see Wolfe et al. 2008). However, the issue arises whether to bring back local and more 'natural' relatives of common varieties to enhance resilience to environmental stresses at the risk of commercial success, or to expressly breed novel cultivars with the desired traits. Although conventional and multi-crop systems share many desirable traits, some (mostly complex) traits have higher priority in organic and multiple-crop circumstances (Wolfe et al. 2008). In the belowground context, these include for example atmospheric $\mathrm{N}$ fixing capabilities, $\mathrm{P}$ mobilisation, disease resistance and weed competition. In those circumstances there is more need for plant vigour to encourage general plant health (Wolfe et al. 2008). Stern (1993) summarises work on legumes which concludes that it is possible to increase atmospheric $\mathrm{N}$ fixation in legumes, so that total amounts of $\mathrm{N}$ fixed exceed plants' requirements. It may be impossible to develop cereal varieties that incorporate a multitude of beneficial functions without affecting grain productivity. However, diversifying crops can help to include all the desired traits by compensating for individual plants' lack of traits and complementing each other at field scale.

Modelling crop productivity at a system level

In order to produce generic and accurate crop models for two or more species, researchers are faced with 
gaps in knowledge making it difficult to: (i) identify the exact mechanisms involved in nutrient facilitation and transfer in different crop combinations (incl. root plasticity and distribution); (ii) identify the most dominant mechanisms and to what extent nutrients are made available and transferred between crops; (iii) the timing of nutrient release (especially in annual-perennial crop mixtures); (iv) and the environmental and soil conditions affecting the activation and efficiency of these mechanisms. Berntsen et al. (2004) have found their extended FASSET crop model (based on winter wheat) to accurately describe resource competition (light, water, nitrogen) and dry matter production in pea-barley intercrops. However, this model does not include temporal changes in canopy structure and more importantly pest and disease occurrences. Additional multi-species models are discussed in Malézieux et al. (2009), but are often limited to geographic areas/climatic zones and growth and yield parameters, and do not consider interactions with the soil microbial communities, or effects on plant pests and diseases. The rates at which nutrients are mineralised and remineralised are still poorly understood, but could have significant implications into how nutrient supply is managed. Studies on functional groups (e.g. PGPR, Rhizobium, AOB, and AMF) are necessary to identify the exact mechanisms by which they affect plant growth (Song et al. 2007b). Detailed studies on the composition of root exudates, as affected by plant development stage and intercropping (competition and interactions with plant-soil system), the factors triggering root exudation, and their metabolism within the soil systems could offer significant insight into how microbial community composition and structure responds to different intercrop circumstances, and which functional groups benefit directly from root exudates. Such information could enable more detailed predictions, on plant/soil biotic effects on weed, pest and disease dynamics, and decomposition rates, to be made. Enzyme activity and decomposition rates of different plant species, require deeper understanding as they affect the level of system interactions and determine the direction of rhizosphere processes, such as nutrient transfer and facilitation, allelopathic and biofumigation properties, soil microbial structure, and relationships within.

\section{Recommendations and conclusions}

We offer the following recommendations as likely effective priorities for further consideration, study and exploitation in relation to the multi-cropping systems in production agriculture, and raise some key questions associated with such concepts.

1. A better understanding is required as to how crop root systems develop when grown in mixtures, and determination of which such combinations offer optimal complementarity in exploitation of the soil volume. Can root architecture be prescribed (e.g. via genotype) or controlled (e.g. via planting patterns) accordingly ? This should include consideration of exploiting complementarity in root traits within species as well as between them.

2. How are root exudation patterns affected when different plants co-exist, and how do the chemicals released under such circumstances affect neighbouring plants, and soil biota such that antagonistic organisms are controlled and desired nutrient cycling functions enhanced ?

3. Interactions between crop mixtures and belowground diversity are unclear, especially the extent to which these are context-dependent ('idiosyncratic'). Are rhizosphere conditioning effects additive in the sense that resultant community structures in crop mixtures are simple sums of the combined rhizospheres of the constituent crops, or do new community manifestations emerge ? How do these in turn affect crop growth and soil functions?

4. The role of mycorrhizae in affecting the functioning of multi-cropping systems is insufficiently understood in terms of both how such fungi affect inter-plant competition and modulate nutrient cycling and transport in the whole system. Do specific mycorrhizal types alter the emergent interplant relationships, and could such factors be used to optimise mixture performance?

5. The effects of multiple plant species, let alone multi-crops, upon soil structural dynamics are hardly known. It is likely that there will be synergistic effects operating via interactions with the soil biota, and hence research in this area is needed and offers particular potential both in terms of affecting crop performance and soil management.

6. It cannot be assumed that cultivars optimised for monocultural circumstances are most suited for multi-cropping scenarios. Both technical and conceptual innovation is needed to deal with the 
challenges of accommodating multi-crop scenarios in breeding programmes, and especially where belowground interactions are involved.

Further insight into how plant species, and particularly mixtures thereof, manipulate the highly complex soil environment and its biotic community via root exudates and resource distribution, and an enhanced understanding of how these effects are manifest under different abiotic conditions is then an overarching research goal. The target is to be able to plan, prescribe and control crop mixtures to maximise overall crop performance and retain or enhance resilience of soil functions. This will require a paradigm-shift in approaches in crop breeding programmes, and a more integrated approach in designing crop production systems which will capitalise on the opportunities multicropping offer.

Acknowledgments This review was conducted partly under the auspices of a project sponsored by Natural England, and we thank Matthew Shepherd of that organisation for his support and interaction in this respect. We thank Mark Tibbett for constructive comment and discussion on earlier versions of the MS, and the journal reviewers for their thoroughness and added insight. We also wholeheartedly acknowledge Martin Wolfe for his insight and remarkable demonstrations of the potential of multi-cropping.

\section{References}

Abawi GS, Widmer TL (2000) Impact of soil health management practices on soilborne pathogens, nematodes and root diseases of vegetable crops. Appl Soil Ecol 15:37-47

Abdel Wahab AM, Abd-Alla MH (1996) Effect of different rates of $\mathrm{N}$-fertilizers on nodulation, nodule activites and growth of two field grown cvs. of soybean. Fert Res 43:37-41

Abdel-Monaim MF, Abo-Elyousr KAM (2012) Effect of preceding and intercropping crops on suppression of lentil damping-off and root rot disease in New Valley - Egypt. Crop Prot 32:41-46

Ae N, Arihara J, Okada K, Yoshihara T, Johansen C (1990) Phosphorus uptake by pigeon pea and its role in cropping systems of the Indian subcontinent. Science 248:477-480

Alsaadawi IS, Al-Uqaili JK, Alrubeaa AJ, Al-Hadithy SM (1986) Allelopathic suppression of weed and nitrification by selected cultivars of Sorghum bicolor (L.) Moench. J Chem Ecol 12:209-219

Altieri MA (1995a) Traditional agriculture. In: Altieri MA (ed) Agroecology, the science of sustainable agriculture, 2nd edn. Westview, Colorado, pp 107-144

Altieri MA (1995b) Integrated pest management. In: Altieri MA (ed) Agroecology, the science of sustainable agriculture, 2nd edn. Westview, Colorado, pp 267-281

Altieri MA (1995c) Plant disease ecology and management. In: Altieri MA (ed) Agroecology, the science of sustainable agriculture, 2nd edn. Westview, Colorado, pp 307-319
Altieri MA (1999) The ecological role of biodiversity in agroecosystems. Agric Ecosyst Environ 74:19-31

Alves BJR, Boddey RM, Urquiaga S (2003) The success of BNF in soybean in Brazil. Plant Soil 252:1-9

Angers DA, Caron J (1998) Plant-induced changes in soil structure: processes and feedbacks. Biogeochemistry 42:55-72

Anil L, Park J, Phipps RH, Miller FA (1998) Temperate intercropping of cereals for forage: a review of the potential for growth and utilization with particular reference to the UK. Grass Forage Sci 53:301-317

Arneja S, Sadana US (2012) Mixed cropping effects on yield, manganese influx, and manganese depletion in the rhizosphere of fodder crops grown in manganese-deficient soil. Commun Soil Sci Plant Anal 43:533-540

Baghestani A, Lemieux C, Leroux GD, Baziramakenga R, Simard RR (1999) Determination of allelochemicals in spring cereal cultivars of different competitiveness. Weed Sci 47:498-504

Bainard LD, Klironomos JN, Gordon AM (2011a) Arbuscular mycorrhizal fungi in tree-based intercropping systems: a review of their abundance and diversity. Pedobiologia 54:57-61

Bainard LD, Koch AM, Gordon AM, Newmaster SG, Thevathasan NV, Klironomos JN (2011b) Influence of trees on the spatial structure of arbuscular mycorrhizal communities in a temperate tree-based intercropping system. Agric Ecosyst Environ 144:13-20

Bainard LD, Koch AM, Gordon AM, Klironomos JN (2012) Temporal and compositional differences of arbuscular mycorrhizal fungal communities in conventional monocropping and tree-based intercropping systems. Soil Biol Biochem 45:172-180

Bambrick AD, Whalen JK, Bradley RL, Cogliastro A, Gordon AM, Olivier A, Thevathasan NV (2010) Spatial heterogeneity of soil organic carbon in tree-based intercropping systems in Quebec and Ontario, Canada. Agrofor Syst 79:343-353

Bartlett M, Ritz K (2011) The zoological generation of soil structure. In: Ritz K, Young M (eds) The architecture and biology of soils, 1st edn. CABI, Wallingford, pp 71-85

Batish DR, Singh HP, Kohli RK, Kaur S (2001) Crop allelopathy and its role in ecological agriculture. J Crop Prod 4:121-161

Bergeron M, Lacombe S, Bradley RL, Whalen J, Cogliastro A, Jutras M, Arp P (2011) Reduced soil nutrient leaching following the establishment of tree-based intercropping systems in eastern Canada. Agrofor Syst 83:321-330

Bergkvist G, Stenberg M, Wetterlind J, Båth B, Elfstrand S (2011) Clover cover crops under-sown in winter wheat increase yield of subsequent spring barley-Effect of $\mathrm{N}$ dose and companion grass. Field Crop Res 120:292-298

Berntsen J, Hauggard-Nielsen H, Olesen JE, Petersen BM, Jensen ES, Thomsen A (2004) Modelling dry matter production and resource use in intercrops of pea and barley. Field Crop Res 88:59-73

Bertrand I, Holloway RE, Armstrong RD, McLaughlin MJ (2003) Chemical characteristics of phosphorus in alkaline soils from southern Australia. Aust J Soil Res 41:61-76

Betencourt E, Duputel M, Colomb B, Desclaux D, Hinsinger P (2012) Intercropping promotes the ability of durum wheat and chickpea to increase rhizosphere phosphorus availability in a low P soil. Soil Biol Biochem 46:181-190

Bever JD, Dickie IA, Facelli E, Facelli JM, Klironomos J, Moora M, Rillig MC, Stock WD, Tibbett M, Zobel M (2010) 
Rooting theories of plant community ecology in microbial interactions. Trends Ecol Evol 25:468-478

Bhowmik PC, Inderjit (2003) Challenges and opportunities in implementing allelopathy for natural weed management. Crop Prot 22:661-671

Blum U, Shafer SR, Lehman ME (1999) Evidence for inhibitory allelopathic interactions involving phenolic acids in field soils: concepts vs. an experimental model. Crit Rev Plant Sci 18:673-693

Boller BC, Nösberger J (1988) Influence of dissimilarities in temporal and spatial N-uptake patterns on ${ }^{15} \mathrm{~N}$-based estimates of fixation and transfer of $\mathrm{N}$ in ryegrass-clover mixtures. Plant Soil 112:167-175

Brown GG, Barois I, Lavelle P (2000) Regulation of soil organic matter dynamics and microbial activity in the drilosphere and the role of interactions with other edaphic functional domains. Eur J Soil Biol 36:177-198

Brussaard L, de Ruiter PC, Brown GG (2007) Soil biodiversity for agricultural sustainability. Agric Ecosyst Environ 121:233244

Chenu C (1995) Extracellular polysaccharides: An interface between microorganisms and soil constituents. In: Huang PM, Berthelin J, Bollag JM, McGill WB, Page AL (eds) Environmental impact of soil component interactions. Volume I. Natural and anthropogenic organics. Lewis, Boca Raton, pp 217-233

Chenu C, Cosentino D (2011) Microbial regulation of soil structural dynamics. In: Ritz K, Young M (eds) The architecture and biology of soils, 1st edn. CABI, Wallingford, pp 37-70

Chifflot V, Rivest D, Olivier A, Cogliastro A, Khasa D (2009) Molecular analysis of arbuscular mycorrhizal community structure and spores distribution in tree-based intercropping and forest systems. Agric Ecosyst Environ 131:32-39

Clemente E, Schaefer C, Novais R, Viana J, Barros N (2005) Soil compaction around Eucalyptus grandis roots: a micromorphological study. Aust J Soil Res 43:139-146

Craine JM, Wedin DA, Chapin FS III, Reich PB (2003) Relationship between the structure of root systems and resource use for 11 North American grassland plants. Plant Ecol 165:85-100

$\mathrm{Cu}$ STT, Hutson J, Schuller KA (2005) Mixed culture of wheat (Triticum aestivum L.) with white lupin (Lupinus albus L.) improves the growth and phosphorus nutrition of the wheat. Plant Soil 272:143-151

Dahlin AS, Stenberg M (2010) Transfer of N from red clover to perennial ryegrass in mixed stands under different cutting strategies. Eur J Agron 33:149-156

Danso SKA, Zapata F, Hardarson G, Fried M (1987) Nitrogen fixation in fababeans as affected by plant population density in sole or intercropped systems with barley. Soil Biol Biochem 19:411-415

de Vallavieille-Pope C (2004) Management of disease resistance diversity of cultivars of a species in single fields: controlling epidemics. CR Soc Biol 327:611-620

den Hollander NG, Bastiaans L, Kropff MJ (2007) Clover as a cover crop for weed suppression in an intercropping design. I. Characteristics of several clover species. Eur J Agron 26:92-103

Dias MC, Conceicao IL, Abrantes I, Cunha MJ (2012) Solanum sisymbrifolium - a new approach for the management of plant-parasitic nematodes. Eur J Plant Pathol 133:171-179
Dobbelaere S, Vanderleyden J, Okon Y (2003) Plant growthpromoting effects of diazotrophs in the rhizosphere. Crit Rev Plant Sci 22:107-149

Dyke GV, Barnard AJ (1976) Suppression of couch grass by Italian ryegrass and broad red-clover undersown in barley and field beans. J Agric Sci 87:123-126

Eisenhauer N (2012) Aboveground-belowground interactions as a source of complementarity effects in biodiversity experiments. Plant Soil 351:1-22

El Dessougi H, Zu Dreele A, Claassen N (2003) Growth and phosphorus uptake of maize cultivated alone, in mixed culture with other crops or after incorporation of their residues. J Plant Nutr Soil Sci 166:254-261

Faget M, Nagel KA, Walter A, Herrera JM, Jahnke S, Schurr U, Temperton VM (2013) Root-root interactions: extending our perspective to be more inclusive of the range of theories in ecology and agriculture using in-vivo analyses. Ann Bot 112:253-266

Farrell JG, Altieri MA (1995) Agroforestry systems. In: Altieri MA (ed) Agroecology, the science of sustainable agriculture, 2nd edn. Westview, Colorado, pp 247-263

Fernández-Aparicio M, Rubiales D (2012) Differential response of pea (Pisum sativum) to Orobanche crenata, Orobanche foetida and Phelipanche aegyptiaca. Crop Prot 31:27-30

Fernández-Aparicio M, Emeran AA, Rubiales D (2008) Control of Orobanche crenata in legumes intercropped with fenugreek (Trigonella foenum-graecum). Crop Prot 27:653-659

Fernández-Aparicio M, Amri M, Kharrat M, Rubiales D (2010) Intercropping reduces Mycosphaerella pinodes severity and delays upward progress on the pea plant. Crop Prot 29:744-750

Fierer N, Jackson RB (2006) The diversity and biogeography of soil bacterial communities. Proc Natl Acad Sci U S A 103:626-631

Fleck NG, Machado CMN, Desouza RS (1984) Efficiency of intercropping in weed-control. Pesq Agrop Brasileira 19:591-598

Fujii Y (2001) Screening and future exploitation of allelopathic plants as alternative herbicides with special reference to hairy vetch. J Crop Prod 4:257-275

Gange AC (1993) Translocation of mycorrhizal fungi by earthworms during early succession. Soil Biol Biochem 25:1021-1026

George SJ, Harper RJ, Hobbs RJ, Tibbett M (2012) A sustainable agricultural landscape for Australia: a review of interlacing carbon sequestration, biodiversity and salinity management in agroforestry systems. Agric Ecosyst Environ 163:28-36

Ghaouti L, Vogt-Kaute W, Link W (2008) Development of locally-adapted faba bean cultivars for organic conditions in Germany through a participatory breeding approach: participatory breeding of faba bean for organic conditions. Euphytica 162:257-268

Giller KE, Cadisch G (1995) Future benefits from biological nitrogen fixation: an ecological approach to agriculture. Plant Soil 174:255-277

Goh KM, Bruce GE (2005) Comparison of biomass production and biological nitrogen fixation of multi-species pastures (mixed herb leys) with perennial ryegrass-white clover pasture with and without irrigation in Canterbury, New Zealand. Agric Ecosyst Environ 110:230-240

Griffiths BS, Hallett PD, Kuan HL, Gregory AS, Watts CW, Whitmore AP (2008a) Functional resilience of soil 
microbial communities depends on both soil structure and microbial community composition. Biol Fertil Soils 44:745-754

Griffiths BS, Liu Q, Wang H, Zhang B, Kuan HL, McKenzie BM, Hallett PD, Neilson R, Daniell TJ (2008b) Restoration of soil physical and biological stability are not coupled in response to plants and earthworms. Ecol Restor 26:102-104

Gunes A, Inal A, Adak MS, Alpaslan M, Bagci EG, Erol T, Pilbeam DJ (2007) Mineral nutrition of wheat, chickpea and lentil as affected by mixed cropping and soil moisture. Nutr Cycl Agroecosyst 78:83-96

Halbrendt JM (1996) Allelopathy in the management of plantparasitic nematodes. J Nematol 28:8-14

Hao W, Ren L, Ran W, Shen Q (2010) Allelopathic effects of root exudates from watermelon and rice plants on Fusarium oxysporum f.sp. niveum. Plant Soil 336:485-497

Hauggaard-Nielsen H, Jensen ES (2001) Evaluating pea and barley cultivars for complementarity in intercropping at different levels of soil $\mathrm{N}$ availability. Field Crop Res 72:185-196

Hauggaard-Nielsen H, Jensen ES (2005) Facilitative root interactions in intercrops. Plant Soil 274:237-250

Hauggaard-Nielsen H, Ambus P, Jensen ES (2001a) Temporal and spatial distribution of roots and competition for nitrogen in pea-barley intercrops - A field study employing ${ }^{32} \mathrm{P}$ technique. Plant Soil 236:63-74

Hauggaard-Nielsen H, Ambus P, Jensen ES (2001b) Interspecific competition, $\mathrm{N}$ use and interference with weeds in peabarley intercropping. Field Crop Res 70:101-109

Hauggaard-Nielsen H, Ambus P, Jensen ES (2003) The comparison of nitrogen use and leaching in sole cropped versus intercropped pea and barley. Nutr Cycl Agroecosys 65:289-300

Hauggaard-Nielsen H, Mundus S, Jensen ES (2009) Nitrogen dynamics following grain legumes and subsequent catch crops and the effects on succeeding cereal crops. Nutr Cycl Agroecosys 84:281-291

Hauggaard-Nielsen H, Holdensen L, Wulfsohn D, Jensen ES (2010) Spatial variation of $\mathrm{N}_{2}$-fixation in field pea (Pisum sativum $\mathrm{L}$.) at the field scale determined by the ${ }^{15} \mathrm{~N}$ natural abundance method. Plant Soil 327:167-184

He XH, Critchley C, Bledsoe C (2003) Nitrogen transfer within and between plants through common mycorrhizal networks (CMNs). Crit Rev Plant Sci 22:531-567

Hinsinger P (2001) Bioavailability of soil inorganic P in the rhizosphere as affected by root-induced chemical changes: a review. Plant Soil 237:173-195

Hinsinger P, Plassard C, Tang C, Jaillard B (2003) Origins of root-mediated $\mathrm{pH}$ changes in the rhizosphere and their responses to environmental constraints: a review. Plant Soil 248:43-59

Hinsinger P, Betencourt E, Bernard L, Brauman A, Plassard C, Shen JB, Tang XY, Zhang FS (2011) P for two, sharing a scarce resource: soil phosphorus acquisition in the rhizosphere of intercropped species. Plant Physiol 156:10781086

Hocking PJ (2001) Organic acids exuded from roots in phosphorus uptake and aluminum tolerance of plants in acid soils. Adv Agron 74:63-97

Høgh-Jensen H, Schjoerring JK (2001) Rhizodeposition of nitrogen by red clover, white clover and ryegrass leys. Soil Biol Biochem 33:439-448
Hooper AM, Hassanali A, Chamberlain K, Khan Z, Pickett JA (2009) New genetic opportunities from legume intercrops for controlling Striga spp. parasitic weeds. Pest Manag Sci 65:546-552

Horst W, Waschkies C (1987) Phosphorus-nutrition of spring wheat (Triticum-Aestivum L) in mixed culture with white lupin (Lupinus albus L). Z Pflanzenernähr Bodenkd 150:1-8

ICRISAT (1981) Proceedings of the international workshop on intercropping, 10-13 Jan 1979. ICRISAT (International crops research institute for the semi-arid tropics), Patancheru, India

Inal A, Gunes A (2008) Interspecific root interactions and rhizosphere effects on salt ions and nutrient uptake between mixed grown peanut/maize and peanut/barley in original saline-sodic-boron toxic soil. J Plant Physiol 165:490-503

Inal A, Gunes A, Zhang F, Cakmak I (2007) Peanut/maize intercropping induced changes in rhizosphere and nutrient concentrations in shoots. Plant Physiol Biochem 45:350-356

Inderjit (2001) Soil: environmental effects on allelochemical activity. Agron J 93:79-84

Isaac ME, Hinsinger P, Harmand JM (2012) Nitrogen and phosphorus economy of a legume tree-cereal intercropping system under controlled conditions. Sci Total Environ 434:7178

Jensen ES (1996) Grain yield, symbiotic $\mathrm{N}_{2}$ fixation and interspecific competition for inorganic $\mathrm{N}$ in pea-barley intercrops. Plant Soil 182:25-38

Jørgensen FV, Jensen ES, Schjoerring JK (1999) Dinitrogen fixation in white clover grown in pure stand and mixture with ryegrass estimated by the immobilized ${ }^{15} \mathrm{~N}$ isotope dilution method. Plant Soil 208:293-305

Kamh M, Horst WJ, Amer F, Mostafa H, Maier P (1999) Mobilization of soil and fertilizer phosphate by cover crops. Plant Soil 211:19-27

Kibblewhite MG, Ritz K, Swift MJ (2008) Soil health in agricultural systems. Phil Trans R Soc B Biol Sci 363:685-701

Kirkegaard JA, Sarwar M (1998) Biofumigation potential of brassicas: I. Variation in glucosinolate profiles of diverse field-grown brassicas. Plant Soil 201:71-89

Klironomos J (2003) Variation in plant response to native and exotic arbuscular mycorrhizal fungi. Ecology 84:22922301

Kloepper J, Rodriguez-Kabana R, Zehnder G, Murphy J, Sikora E, Fernandez C (1999) Plant root-bacterial interactions in biological control of soilborne diseases and potential extension to systemic and foliar diseases. Australas Plant Pathol 28:2126

Kluth C, Buhre C, Varrelmann M (2010) Susceptibility of intercrops to infection with Rhizoctonia solani AG 2-2 IIIB and influence on subsequently cultivated sugar beet. Plant Pathol 59:683-692

Kuhlmann H (1990) Importance of the subsoil for the K nutrition of crops. Plant Soil 127:129-136

Kumar AS, Mody K, Jha B (2007) Bacterial exopolysaccharides - a perception. J Basic Microbiol 47:103-117

Kurdali F, Domenach AM, Bardin R (1990) Alder-poplar associations: determination of plant nitrogen sources by isotope techniques. Biol Fertil Soils 9:321-329

Lacombe S, Bradley RL, Hamel C, Beaulieu C (2009) Do treebased intercropping systems increase the diversity and stability of soil microbial communities? Agric Ecosyst Environ $131: 25-31$ 
Lehmann J (2003) Subsoil root activity in tree-based cropping systems. Plant Soil 255:319-331

Lei T, Zhan W, Xiao J, Huang X, Mao J (2005) Water use efficiency of a mixed cropping system of corn with grasses. Int J Sustain Dev World 12:55-59

Lemerle D, Verbeek B, Orchard B (2001) Ranking the ability of wheat varieties to compete with Lolium rigidum. Weed Res 41:197-209

Li L, Tang C, Rengel Z, Zhang FS (2004) Calcium, magnesium and microelement uptake as affected by phosphorus sources and interspecific root interactions between wheat and chickpea. Plant Soil 261:29-37

Li L, Sun J, Zhang F, Guo T, Bao X, Smith FA, Smith SE (2006) Root distribution and interactions between intercropped species. Oecologia 147:280-290

Li L, Li S, Sun J, Zhou L, Bao X, Zhang H, Zhang F (2007) Diversity enhances agricultural productivity via rhizosphere phosphorus facilitation on phosphorus-deficient soils. Proc Natl Acad Sci U S A 104:11192-11196

Li H, Shen J, Zhang F, Clairotte M, Drevon JJ, Le Cadre E, Hinsinger P (2008) Dynamics of phosphorus fractions in the rhizosphere of common bean (Phaseolus vulgaris L.) and durum wheat (Triticum turgidum durum L.) grown in monocropping and intercropping systems. Plant Soil 312:139-150

Li H, Shen J, Zhang F, Marschner P, Cawthray G, Rengel Z (2010) Phosphorus uptake and rhizosphere properties of intercropped and monocropped maize, faba bean, and white lupin in acidic soil. Biol Fertil Soils 46:79-91

Li L, Sun J, Zhang F (2011) Intercropping with wheat leads to greater root weight density and larger below-ground space of irrigated maize at late growth stages. Soil Sci Plant Nutr 57:61-67

Liebman M (1995) Polyculture cropping systems. In: Altieri MA (ed) Agroecology, the science of sustainable agriculture, 2nd edn. Westview, Colorado, pp 205-218

Liebman M, Dyck E (1993) Crop rotation and intercropping strategies for weed management. Ecol Appl 3:92-122

Lins RD, Colquhoun JB, Mallory-Smith CA (2006) Investigation of wheat as a trap crop for control of Orobanche minor. Weed Res 46:313-318

Lithourgidis AS, Dordas CA, Damalas CA, Vlachostergios DN (2011) Annual intercrops: an alternative pathway for sustainable agriculture. Aust J Crop Sci 5:396-410

Lovett JV (1982) Agro-chemical alternatives in a future agriculture. Biol Agric Hortic 1:15-27

Lynch JP, Brown KM (2012) New roots for agriculture: exploiting the root phenome. Philos Trans R Soc B Biol Sci 367:1598-1604

Magdoff F (1995) Soil quality and management. In: Altieri MA (ed) Agroecology, the science of sustainable agriculture, 2nd edn. Westview, Colorado, pp 349-364

Malézieux E, Crozat Y, Dupraz C, Laurans M, Makowski D, Ozier-Lafontaine H, Rapidel B, De Tourdonnet S, ValantinMorison M (2009) Mixing plant species in cropping systems: concepts, tools and models. A review. Agron Sustain Dev 29:43-62

Manna M, Singh M (2001) Long-term effects of intercropping and bio-litter recycling on soil biological activity and fertility status of sub-tropical soils. Bioresour Technol 76:143-150

Marschner H, Treeby M, Romheld V (1989) Role of rootinduced changes in the rhizosphere for iron acquisition in higher-plants. Z Pflanzenernähr Bodenkd 152:197-204
Martin MPLD, Snaydon RW (1982) Root and shoot interactions between barley and field beans when intercropped. J Appl Ecol 19:263-272

Materechera SA, Kirby JM, Alston AM, Dexter AR (1994) Modification of soil aggregation by watering regime and roots growing through beds of large aggregates. Plant Soil 160:57-66

Mattner SW, Porter IJ, Gounder RK, Shanks AL, Wren DJ, Allen D (2008) Factors that impact on the ability of biofumigants to suppress fungal pathogens and weeds of strawberry. Crop Prot 27:1165-1173

McIntyre BD, Riha SJ, Ong CK (1997) Competition for water in a hedge-intercrop system. Field Crop Res 52:151-160

Mohler CL, Liebman M (1987) Weed productivity and composition in sole crops and intercrops of barley and field pea. J Appl Ecol 24:685-699

Monteiro RA, Balsanelli E, Wassem R, Morin AM, BrusamarelloSantos LCC, Schmidt MA, Tadra-Sfeir MZ, Pankievicz VCS, Cruz LM, Chubatsu LS, Pedrosa FO, Souza EM (2012) Herbaspirillum-plant interactions: microscopical, histological and molecular aspects. Plant Soil 356:175-196

Mooney SJ, Pridmore TP, Helliwell J, Bennett MJ (2012) Developing X-ray computed tomography to noninvasively image 3-d root systems architecture in soil. Plant Soil 352:1-22

Motisi N, Montfort F, Faloya V, Lucas P, Doré T (2009) Growing Brassica juncea as a cover crop, then incorporating its residues provide complementary control of Rhizoctonia root rot of sugar beet. Field Crop Res 113:238-245

Mushagalusa GN, Ledent J, Draye X (2008) Shoot and root competition in potato/maize intercropping: effects on growth and yield. Environ Exp Bot 64:180-188

Neumann G, Römheld V (1999) Root excretion of carboxylic acids and protons in phosphorus-deficient plants. Plant Soil 211:121-130

Neumann A, Schmidtke K, Rauber R (2007) Effects of crop density and tillage system on grain yield and $\mathrm{N}$ uptake from soil and atmosphere of sole and intercropped pea and oat. Field Crop Res 100:285-293

Oelbermann M, Echarte L (2011) Evaluating soil carbon and nitrogen dynamics in recently established maize-soyabean inter-cropping systems. Eur J Soil Sci 62:35-41

Osmont KS, Sibout R, Hardtke CS (2007) Hidden branches: developments in root system architecture. Annu Rev Plant Physiol Plant Mol Biol 58:93-113

Pappa VA, Rees RM, Walker RL, Baddeley JA, Watson CA (2011) Nitrous oxide emissions and nitrate leaching in an arable rotation resulting from the presence of an intercrop. Agric Ecosyst Environ 141:153-161

Pellissier F, Souto XC (1999) Allelopathy in northern temperate and boreal semi-natural woodland. Crit Rev Plant Sci 18:637-652

Pierret A, Hartmann C, Maeght JL, Pages L (2011) Biotic regulation: plants. In: Ritz K, Young M (eds) The architecture and biology of soils, 1st edn. CABI, Wallingford, pp 86-103

Poggio SL (2005) Structure of weed communities occurring in monoculture and intercropping of field pea and barley. Agric Ecosyst Environ 109:48-58

Putnam AR, Defrank J, Barnes JP (1983) Exploitation of allelopathy for weed control in annual and perennial cropping systems. J Chem Ecol 9:1001-1010 
Qiao YJ, Li ZZ, Wang X, Zhu B, Hu YG, Zeng ZH (2012) Effect of legume-cereal mixtures on the diversity of bacterial communities in the rhizosphere. Plant Soil Environ 58:174-180

Reddell P, Spain AV (1991) Earthworms as vectors of viable propagules of mycorrhizal fungi. Soil Biol Biochem 23:767-774

Rice EL (1985) Overview of allelopathy. Abstr Pap Am Chem Soc 190:2

Riesinger P, Herzon I (2010) Symbiotic nitrogen fixation in organically managed red clover-grass leys under farming conditions. Acta Agric Scand Sect B Soil Plant 60:517-528

Rillig MC, Mummey DL (2006) Mycorrhizas and soil structure. New Phytol 171:41-53

Ritz K (2006) Fungal roles in transport processes in soils. In: Gadd GM (ed) Fungi in biogeochemical cycles, 1st edn. Cambridge University Press, London, pp 51-73

Ritz K (2011) Views of the underworld: In situ visualisation of soil biota. In: Ritz K, Young IM (eds) Architecture and biology of soils. CABI, Wallingford, pp 1-12

Ritz K, Young IM (2004) Interactions between soil structure and fungi. Mycologist 18:52-59

Rizvi SJH, Tahir M, Rizvi V, Kohli RK, Ansari A (1999) Allelopathic interactions in agroforestry systems. Crit Rev Plant Sci 18:773-796

Römheld V (1991) The role of phytosiderophores in acquisition of iron and other micronutrients in graminaceous species: an ecological approach. Plant Soil 130:127-134

Roumet C, Picon-Cochard C, Dawson LA, Joffre R, Mayes R, Blanchard A, Brewer MJ (2006) Quantifying species composition in root mixtures using two methods: near-infrared reflectance spectroscopy and plant wax markers. New Phytol 170:631-638

Sanchez PA (1995) Science in agroforestry. Agrofor Syst 30:5-55

Saucke H, Ackermann K (2006) Weed suppression in mixed cropped grain peas and false flax (Camelina sativa). Weed Res 46:453-461

Schmidt O, Curry JP (2001) Population dynamics of earthworms (Lumbricidae) and their role in nitrogen turnover in wheat and wheat-clover cropping systems. Pedobiologia 45:174-187

Schmidt O, Curry JP, Hackett RA, Purvis G, Clements RO (2001) Earthworm communities in conventional wheat monocropping and low-input wheat-clover intercropping systems. Ann Appl Biol 138:377-388

Sears PD, Evans LT (1953) Pasture growth and soil fertility. NZ J Sci Techol A35 Suppl 1:42-52

Seiter S, Horwath WR (1999) The fate of tree root and pruning nitrogen in a temperate climate alley cropping system determined by tree-injected ${ }^{15} \mathrm{~N}$. Biol Fertil Soils 30:61-68

Shigaki T, Gray FA, Delaney RH, Koch DW (1998) Evaluation of host resistance and intercropping for management of the northern root-knot nematode in sainfoin, Onobrychis viciifolia. J Sustain Agric 12:23-39

Singh HP, Batish DR, Kohli RK (2003) Allelopathic interactions and allelochemicals: new possibilities for sustainable weed management. Crit Rev Plant Sci 22:239-311

Song YN, Zhang FS, Marschner P, Fan FL, Gao HM, Bao XG, Sun JH, Li L (2007a) Effect of intercropping on crop yield and chemical and microbiological properties in rhizosphere of wheat (Triticum aestivum L.), maize (Zea mays L.), and faba bean (Vicia faba L.). Biol Fertil Soils 43:565-574

Song YN, Marschner P, Li L, Bao XG, Sun JH, Zhang FS (2007b) Community composition of ammonia-oxidizing bacteria in the rhizosphere of intercropped wheat (Triticum aestivum L.), maize (Zea mays L.), and faba bean (Vicia faba L.). Biol Fertil Soils 44:307-314

Stern WR (1993) Nitrogen fixation and transfer in intercrop systems. Field Crop Res 34:335-356

Szumigalski AR, Van Acker RC (2006) Nitrogen yield and land use efficiency in annual sole crops and intercrops. Agron J 98:1030-1040

Tang C, Yu Q (1999) Impact of chemical composition of legume residues and initial soil $\mathrm{pH}$ on $\mathrm{pH}$ change of a soil after residue incorporation. Plant Soil 215:29-38

Tarafdar J, Jungk A (1987) Phosphatase-activity in the rhizosphere and its relation to the depletion of soil organic phosphorus. Biol Fertil Soils 3:199-204

Thevathasan NV, Gordon AM, Simpson JA, Reynolds PE, Price G, Zhang P (2004) Biophysical and ecological interactions in a temperate tree-based intercropping system. J Crop Improv 12:339-363

Thorsted MD, Weiner J, Olesen JE (2006) Above- and below-ground competition between intercropped winter wheat Triticum aestivum and white clover Trifolium repens. J Appl Ecol 43:237-245

Tisdall JM, Oades JM (1983) Organic matter and water-stable aggregates in soils. J Soil Sci 33:141-163

Tosti G, Guiducci M (2010) Durum wheat-faba bean temporary intercropping: effects on nitrogen supply and wheat quality. Eur J Agron 33:157-165

Tosti G, Thorup-Kristensen K (2010) Using coloured roots to study root interaction and competition in intercropped legumes and non-legumes. J Plant Ecol 3:191-199

Trenbath BR (1993) Intercropping for the management of pests and diseases. Field Crop Res 34:381-405

Treseder KK, Turner KM (2007) Glomalin in ecosystems. Soil Sci Soc Am J 71:1257-1266

Uvarov AV (2009) Inter- and intraspecific interactions in lumbricid earthworms: their role for earthworm performance and ecosystem functioning. Pedobiologia 53:1-27

Van Dam A (2006) Understanding the reduction of nitrogen leaching by catch crops. Published $\mathrm{PhD}$ Thesis, Wageningen University, Wageningen, $171 \mathrm{pp}$.

Van Noordwijk M, Hairiah K, Partoharjono S, Labios RV, Garrity DP (1996) Food-crop-based production systems as sustainable alternatives for Imperata grasslands? Agrofor Syst 36:55-82

Vandermeer J (1989) The ecology of intercropping. Cambridge University Press, Cambridge

Wang D, Marschner P, Solaiman Z, Rengel Z (2007a) Belowground interactions between intercropped wheat and Brassicas in acidic and alkaline soils. Soil Biol Biochem 39:961-971

Wang D, Marschner P, Solaiman Z, Rengel Z (2007b) Growth, P uptake and rhizosphere properties of intercropped wheat and chickpea in soil amended with iron phosphate or phytate. Soil Biol Biochem 39:249-256

Wang Y, Zhang B, Lin L, Zepp H (2011) Agroforestry system reduces subsurface lateral flow and nitrate loss in Jiangxi Province, China. Agric Ecosyst Environ 140:441-453

Whitmore AP, Schröder JJ (2007) Intercropping reduces nitrate leaching from under field crops without loss of yield: a modelling study. Eur J Agron 27:81-88

Witter E, Johansson G (2001) Potassium uptake from the subsoil by green manure crops. Biol Agric Hortic 19:127-141 
Wolfe MS (2000) Agriculture: crop strength through diversity. Nature 406:681-682

Wolfe MS, Baresel JP, Desclaux D, Goldringer I, Hoad S, Kovacs G, Löschenberger F, Miedaner T, Østergård H, Lammerts Van Bueren ET (2008) Developments in breeding cereals for organic agriculture. Euphytica 163:323-346

Xiao Y, Li L, Zhang F (2004) Effect of root contact on interspecific competition and $\mathrm{N}$ transfer between wheat and fababean using direct and indirect ${ }^{15} \mathrm{~N}$ techniques. Plant Soil 262:45-54

Yao Q, Li X, Ai W, Christie P (2003) Bi-directional transfer of phosphorus between red clover and perennial ryegrass via arbuscular mycorrhizal hyphal links. Eur J Soil Biol 39:47-54

Yong T, Yang W, Xiang D, Chen X (2012) Effects of different cropping modes on crop root growth, yield, and rhizosphere soil microbes' number. Chin J Appl Ecol 23:125-132

Young I, Blanchart E, Chenu C, Dangerfield M, Fragoso C, Grimaldi M, Ingram J, Monrozier L (1998) The interaction of soil biota and soil structure under global change. Glob Chang Biol 4:703-712

Zarea MJ, Ghalavand A, Goltapeh EM, Rejali F, Zamaniyan M (2009) Effects of mixed cropping, earthworms (Pheretima sp.), and arbuscular mycorrhizal fungi (Glomus mosseae) on plant yield, mycorrhizal colonization rate, soil microbial biomass, and nitrogenase activity of free-living rhizosphere bacteria. Pedobiologia 52:223-235

Zarea MJ, Karimi N, Gollapeh EM, Ghalavand A (2011) Effect of cropping system and arbuscular mycorrhizal fungi on soil microbial activity and root nodule nitrogenase. J Saudi Soc Agric Sci 10:109-120
Zhang F, Li L (2003) Using competitive and facilitative interactions in intercropping systems enhances crop productivity and nutrient-use efficiency. Plant Soil 248:305-312

Zhang E, Li L, Huang G, Huang P, Chai Q (2002) Regulation of fertilizer application on yield and root growth of spring wheat-faba bean intercropping system. Chin J Appl Ecol 13:939-942

Zhang F, Shen J, Li L, Liu X (2004) An overview of rhizosphere processes related with plant nutrition in major cropping systems in China. Plant Soil 260:89-99

Zhang NN, Sun YM, Li L, Wang ET, Chen WX, Yuan HL (2010a) Effects of intercropping and Rhizobium inoculation on yield and rhizosphere bacterial community of faba bean (Vicia faba L.). Biol Fertil Soils 46:625-639

Zhang YL, Chen LJ, Sun CX, Wu ZJ, Chen ZH, Dong GH (2010b) Soil hydrolase activities and kinetic properties as affected by wheat cropping systems of northeastern China. Plant Soil Environ 56:526-532

Zhou X, Yu G, Wu F (2011) Effects of intercropping cucumber with onion or garlic on soil enzyme activities, microbial communities and cucumber yield. Eur J Soil Biol 47:279-287

Zuo Y, Zhang F (2008) Effect of peanut mixed cropping with gramineous species on micronutrient concentrations and iron chlorosis of peanut plants grown in a calcareous soil. Plant Soil 306:23-36

Zuo Y, Li X, Cao Y, Zhang F, Christie P (2003) Iron nutrition of peanut enhanced by mixed cropping with maize: possible role of root morphology and rhizosphere microflora. J Plant Nutr 26:2093-2110 